IZA DP No. 7772

Aid to Jobless Workers in Florida in the Face of the Great Recession: The Interaction of Unemployment Insurance and the Supplemental Nutritional Assistance Program

Colleen M. Heflin

Peter R. Mueser

November 2013 


\title{
Aid to Jobless Workers in Florida in the Face of the Great Recession: The Interaction of Unemployment Insurance and the Supplemental Nutritional Assistance Program
}

\author{
Colleen M. Heflin \\ University of Missouri \\ Peter R. Mueser \\ University of Missouri \\ and IZA
}

\section{Discussion Paper No. 7772 \\ November 2013}

\author{
IZA \\ P.O. Box 7240 \\ 53072 Bonn \\ Germany \\ Phone: +49-228-3894-0 \\ Fax: +49-228-3894-180 \\ E-mail: iza@iza.org
}

Any opinions expressed here are those of the author(s) and not those of IZA. Research published in this series may include views on policy, but the institute itself takes no institutional policy positions. The IZA research network is committed to the IZA Guiding Principles of Research Integrity.

The Institute for the Study of Labor (IZA) in Bonn is a local and virtual international research center and a place of communication between science, politics and business. IZA is an independent nonprofit organization supported by Deutsche Post Foundation. The center is associated with the University of Bonn and offers a stimulating research environment through its international network, workshops and conferences, data service, project support, research visits and doctoral program. IZA engages in (i) original and internationally competitive research in all fields of labor economics, (ii) development of policy concepts, and (iii) dissemination of research results and concepts to the interested public.

IZA Discussion Papers often represent preliminary work and are circulated to encourage discussion. Citation of such a paper should account for its provisional character. A revised version may be available directly from the author. 


\title{
ABSTRACT \\ Aid to Jobless Workers in Florida in the Face of the Great Recession: The Interaction of Unemployment Insurance and the Supplemental Nutritional Assistance Program ${ }^{*}$
}

\begin{abstract}
Although many programs redistribute resources in the U.S., two program were central in providing a safety net for those facing hardship during the Great Recession: the Supplemental Nutrition Assistance Program (SNAP), which grew to 47.7 million people in January 2013 - or 15.1 percent of all Americans - and the Unemployment Insurance Program (UI), which more than doubled with the onset of the recession, reaching a seasonally adjusted maximum of 6.5 million recipients in June 2009. We examine state administrative data from Florida for SNAP and UI from late 2005 through early 2010. We focus on two research questions: 1 . In the face of caseload growth and compositional change in both programs, how has joint participation in UI among SNAP recipients changed? How much of the increase in joint participation is driven by changes in the characteristics of individuals participating in SNAP? How much is driven by the changing economic and policy conditions? 2. How has the role of UI changed for SNAP participants, and in particular how have patterns of combined usage evolved during this period? We find that the number of families relying on both SNAP and UI together ballooned with the Great Recession, and that the patterns changed as expected, with UI growing dramatically in relative importance. At the same time, only a minority of those swelling the ranks of SNAP obtained benefits from the UI program, suggesting that the current safety net has important limitations in times of serious economic distress.
\end{abstract}

JEL Classification: $\quad \mathrm{H} 24, \mathrm{H} 53, \mathrm{I38}, \mathrm{J} 65$

Keywords: Great Recession, social insurance, safety net, SNAP, Unemployment Insurance

Corresponding author:

Peter Mueser

Department of Economics

University of Missouri

Columbia, MO 65203

USA

E-mail: MueserP@missouri.edu

\footnotetext{
* This research was supported by the Economic Research Service of the U.S. Department of Agriculture. We wish to thank participants and conference organizers of the IZA/OECD/World Bank conference on Safety Nets and Benefit Dependence: Evidence and Policy Implications (Paris, May 2013), who provided useful comments.
} 


\section{Introduction}

The U.S. economy is undergoing a major restructuring. Unemployment rates persist at historic highs, and economic growth is slower than in any recovery since the Great Depression. The average duration of unemployment spells during the recession was higher than in any other postWar recession and there is evidence that a growing number of workers are becoming discouraged and leaving the labor market. As a result, in 2011 the US official poverty rate was at 15 percent, close to its maximum in over 45 years, and food insecurity rates were at a measured high of 14.9 percent, suggesting that American families are facing levels of hardship that are unprecedented in recent memory (Coleman-Jensen, et al. 2012; DeNavis-Walt, Proctor and Smith 2012).

Unlike the Great Depression, which resulted in the creation of a set of both temporary and more permanent social programs to meet the needs of the low-income population, the Great Recession has been weathered using the existing structure of both social insurance and social welfare programs. In particular, participation in the Supplemental Nutrition Assistance Program (SNAP) ${ }^{1}$, a means-tested program designed to provide food assistance for the poor, has grown to 47.7 million people in January 2013 — or 15.1 percent of all Americans. Similarly, participation in the Unemployment Insurance Program (UI), a social insurance program designed to buffer middle income households from short-term unemployment shocks, more than doubled with the onset of the recession, reaching a seasonally adjusted maximum of 6.5 million recipients in June 2009 (U.S. Department of Labor 2013a).

Because SNAP is a means-tested program and UI a social insurance program, population targets, application procedures, and eligibility requirements are quite different across the programs. It might be assumed that, since UI has a relatively high prior earnings eligibility

\footnotetext{
${ }^{1}$ The Food Stamp Program was renamed Supplemental Nutrition Assistance Program in fall of 2008. We refer to the program as SNAP throughout the current paper. National caseload statistics are available through the U.S. Department of Agriculture (2013).
} 
requirement and UI benefit levels are tied to prior earnings, individuals receiving UI would have income levels too high to qualify for SNAP. However, many states have UI maximum benefit levels low enough to allow UI participating households to be eligible for SNAP. For example, in Florida the maximum weekly UI benefit level is $\$ 275$, allowing even a single individual with no other income to be eligible for SNAP, and allowing for substantial payments for a large household. Additionally, the exceedingly high durations of unemployment experienced in the current economic downturn increase the possibility that households could exhaust UI benefits but remain unemployed and turn to SNAP as a means of economic support.

As a consequence, although these programs are designed with different purposes and different target populations, both may be relevant for poor families. The most common view of how the two programs may be combined envisions a UI recipient exhausting benefits and, in the face of continuing unemployment, turning to SNAP for additional assistance. SNAP then serves as a complement to UI, helping to make the safety net more comprehensive. However, with the Great Recession, we may well expect the dynamics to change. The dramatic growth in UI resulting from rule changes extending the period of eligibility mean that exhaustion of benefits is less common. At the same time, UI benefits combined with SNAP may provide substantial additional help to those suffering most as a result of the economic downturn. In this case, UI may help to bolster the safety net during the hardest times.

Policymakers need to understand the extent to which these two roles occur. If the interaction of the two programs shifted dramatically with recession, the appropriate government response to future downturns could rely on UI benefit extensions like those observed in the Great Recession. On the other hand, if our analysis suggests that UI was of limited value to those at the bottom of the income distribution, it will be clear that broader-based approaches may be 
necessary, either involving expansions in SNAP or other means tested programs, or by developing new programs.

The results we present provide a mixed picture. We confirm that some UI exhaustees do turn to SNAP, as the common view suggests, but we find that this was relatively uncommon prior to the recession and that it increased relatively little with the downturn. However, we find that the number of families relying on SNAP and UI together ballooned with the Great Recession, and that the patterns changed as expected, with UI growing dramatically in relative importance. At the same time, only a minority of those swelling the ranks of SNAP obtained benefits from the UI program, suggesting that the current safety net has important limitations in times of serious economic distress.

We examine state administrative data from Florida for SNAP and UI from late 2005 through early 2010. We focus on two research questions:

1. In the face of caseload growth and compositional change in both programs, how has joint participation in UI among SNAP recipients changed? How much of the increase in joint participation is driven by changes in the characteristics of individuals participating in SNAP? How much is driven by the changing economic and policy conditions?

2. How has the role of UI changed for SNAP participants, and in particular how have patterns of combined usage evolved during this period? For example, with the onset of the Great Recession are SNAP participants more likely to participate in UI concurrent or move to SNAP only after exhausting UI?

Analyses based on Florida are ideal for addressing these research questions. Florida is the fourth largest state in the United States by population with 19.3 million residents and the $22^{\text {nd }}$ 
largest state by total land area. Florida entered the twenty-first century with a strong economy whose performance mirrored that of the national economy. From 1996-2002, the state annual unemployment rate in Florida stayed within two-tenths of a percentage point of the national average. In 2003, however, Florida's unemployment rate began to fall sharply ahead of the also declining national unemployment rate (see Figure 1). While economists debated the consequences of having a national unemployment rate of 4.6 percent in 2006, the annual unemployment rate reached a low of 3.4 percent in 2006 in Florida. Then, as the national annual unemployment rate held steady in 2007 at the 2006 low of 4.6 percent, Florida's unemployment rate began to climb. In the first half of 2008, Florida's unemployment rate jumped to 6.2 percent while the national unemployment rate remained at 4.8 percent. As of December 2009, Florida had the sixth highest state unemployment rate in the country, 11.8 percent, a 4.2 percentage-point increase over the December 2008 level and a more than three-fold increase in less than three years. In contrast to other states that witnessed their largest declines in employment in manufacturing, Florida lost over 250 thousand jobs in the construction industry between December 2006 and December 2009 (U.S. Bureau of Labor Statistics 2010). Insofar as Florida has a combination of a diverse labor force, a strong service sector economy, and a large aging population, results from our analysis of Florida may well preview the coming American condition.

\section{SNAP and UI in Context}

The Supplemental Nutrition Assistance Program (SNAP) is a means tested federal program that provides households with benefits accessed through an electronic debit card that can be used for food purchases. To be eligible, households must either have gross incomes that are less than 130 percent of the U.S. poverty level (approximately $\$ 2500$ per month for a family of 4) or be 
categorically eligible through participation in a state Temporary Assistance for Needy Families Program (TANF), general assistance (GA) or the Supplemental Security Income program. Although details of eligibility and program administration differ across states, the program's basic structure and payment amounts are set at the federal level. Benefits are reduced by $\$ 0.33$ for each dollar of net income. While not generous, benefits can be of importance for poor families. A family of four with no income would be eligible for a monthly payment of $\$ 632$ as of 2013.

SNAP benefit levels are adjusted for inflation annually. However, as part of the American Recovery and Reinvestment Act, SNAP benefits were increased by 13.6 percent in April 2009 and then maintained in nominal terms, until dropping to their previous inflationadjusted levels on November 1, 2013. Minimum benefit levels for one- and two-person families also increased during our study period from $\$ 10$ per month to $\$ 14$ in June 2008 and to $\$ 16$ in April 2009.

For households with children, elderly individuals or other dependents (e.g., disabled members)—the overwhelming majority of the SNAP caseload—eligibility is not time-limited, and no work or job-search requirements apply. In contrast, households consisting of able bodied adults without dependents (often referred to as “ABAWDs" in the literature) are subject to a three-month limit on receipt. Once that time limit is exceeded, ABAWDs may be required to obtain employment or engage in job search activities as a condition for continued receipt. Such restrictions are waived in those counties with greater unemployment rates, and states may also choose to exempt a portion of their caseload from these rules. ${ }^{2}$

\footnotetext{
${ }^{2}$ In Florida, up through 2007, just under 6 percent of individuals in the caseload aged 18-65 were classified as ABAWDs. Time limits applying to this group were automatically lifted in response to increasing unemployment rates with the onset of the recession. The ABAWD proportion doubled by the end of 2009, suggesting that removal of limits for ABAWDs probably had a small impact on SNAP caseload growth in Florida.
} 
Florida removed the asset and vehicle tests for most families in 2001. Simplified reporting was adopted in 2003 (Cody, Nogales and Martin 2008). Although narrow categorical eligibility was in place in Florida during this period, the number of SNAP recipients affected by this provision was very small (Falk and Aussenberg 2013). Changes in rules increasing the number of individuals subject to less restrictive SNAP eligibility rules ("broad based categorical eligibility”) came into effect in Florida in July 2010, after the period to which our data apply. Hence, there are no significant changes in the formal SNAP eligibility rules in Florida during the period of our study

The Department of Children and Families (DCF) in Florida serviced the third largest SNAP caseload in the country with 3.6 million individuals in December 2012, accounting for 7.5 percent of the national caseload of 47.8 million participants (U.S. Department of Agriculture 2013). Figure 2 lists the number of households served in Florida and the U.S. from January 2003 to January 2010. While growth in the Florida SNAP caseload followed the national trend closely from the beginning of 2003 to mid-2007, from May 2007 to the present, the rate of growth in the SNAP caseload has been substantially greater than that of the nation. ${ }^{3}$

Located in the southeast of the United States, Florida is known for its temperate climate and is a primary destination for retirees. As a consequence, a larger share of the SNAP caseload is composed of elderly adults as compared to the national average (20.2 versus 16.5 percent). Some 36.9 percent of the caseload is made up of children, 16.7 percent disabled non-elderly adults, and 15.9 percent single adults heading households with children. ${ }^{4}$

\footnotetext{
${ }^{3}$ Emergency SNAP payments are omitted from Figure 2 and all analyses in our paper. Although insignificant for the nation as a whole, for Florida, emergency payments cause noticeable temporary spikes in SNAP caseloads following major hurricanes, which occur every few years.

${ }^{4}$ Based on 2012 caseloads (U.S. Department of Agriculture 2012).
} 
Omitting subsidies tied to the tax system, ${ }^{5}$ SNAP is by far the most important meanstested program in the U.S., providing support to approximately one in seven Americans by 2013, twice the proportion in the early 2000s. In comparison to social assistance programs in other developed countries, SNAP benefits are modest, but the proportion of the population receiving such aid, especially with recent increases, is comparable or even above the proportion receiving social assistance aid in many other countries. In Britain, the proportion receiving social assistance (excluding housing support) peaked at over 10 percent in the 1990s, but it had declined to about 6 percent by 2005 (Cappellari and Jenkins 2013). Even with the growth following the Great Recession, it remains below that in the U.S. Through the 1990s, social assistance participation rates in Canada were in the range of 10 percent (Hansen et al. 2013). Social assistance rates in Germany peaked at around 12 percent in 2006-2011, after increasing from around 8 percent in the 1990s (Körnigs 2013).

The Unemployment Insurance Program is a joint federal-state program that operates as social insurance for short-term periods of unemployment. In order to qualify, workers must meet both monetary eligibility guidelines, based primarily on employment and total earnings over a 15-month period, and non-monetary requirements, which are determined primarily by age, reason for work separation and availability for work. Historically, regular state UI benefits for most recipients last for 26 weeks. After exhausting regular benefits, recipients may be eligible for additional weeks of benefits funded under federal legislation, contingent on the condition of the state and national economies. Significant state variation exists in the operation of UI with regard to eligibility, payment levels, and duration of benefits.

\footnotetext{
${ }^{5}$ The most important subsidy of this kind is the Earned Income Tax Credit, which provides tax credits, and, in some cases, cash assistance to the working poor. However, because credits are tied to paid employment, it provides relatively little support for the very poorest households. Although an important source of support for participants, it largely compensates for payroll and other taxes that workers pay.
} 
At the national level, one of the more troubling aspects of the recent recession is the extended periods of unemployment suffered by many workers. Since 1965, the median duration of unemployment has remained below 10 weeks with only two exceptions. In both the mid1980s and early 2000's the median duration crossed the 10 week mark but still remained below 13 weeks. In December, 2009, however, the median duration of unemployment was 20.5 weeks (Federal Reserve Bank of St. Louis 2010). This unique aspect of the recession means that not only were more people unemployed, but they remained unemployed for periods that were dramatically longer than at any time in recent history. In Florida, according to data from the fourth quarter for 2012, the average duration of UI benefits was 20.3 weeks, above the national average of 17.1 weeks. The proportion of recipients exhausting Unemployment Insurance benefits in Florida was 70.1 percent, well above the national average of 47.2 percent and the highest in the country (U.S. Department of Labor 2013b). Thus, economic conditions in Florida provide a particularly challenging economic environment, so the economic impacts are likely to be particularly clear.

As a result of seven legislative actions at the U.S. federal level from June 2008 to April 2010, the Unemployment Insurance program was altered to extend the maximum duration of receipt up to 99 weeks in some states. With four tiers of benefit duration tied to the state unemployment rate, states were encouraged to liberalize eligibility standards. While states fund regular unemployment insurance benefits from taxes received from state employers, the federal government fully funded extended benefits received under emergency legislation from July 2008 to May 2010. As late as 2011, the number of recipients receiving such federal extended benefits exceeded the number on regular state UI benefits at the national level. 
In Florida, monetary eligibility requires employment in two of the first four of the last five quarters and total minimum earnings of $\$ 3,200$ over this period. Workers must be between the ages of 18 and 65 to qualify and have separated from their employer due to layoff, compulsory retirement, in order to move with a military spouse, or because of personal illness. Florida does not provide a dependence allowance and benefits range from a minimum weekly level of $\$ 32$ to a maximum of $\$ 275$, among the lowest in the country.

A number of studies have considered the role of these two programs in the Great Recession. Federal funding for SNAP grew faster as result of the Great Recession than for any other U.S. safety net program. Aggregate expenditures increased from $\$ 30$ billion in 2007 to $\$ 65$ billion in 2010, causing real U.S. per capita spending to double from $\$ 136$ to $\$ 287$. Although the size of the average benefit amount did increase modestly over this period, the rise in expenditures was largely driven by the rise in the number of recipients (Moffit 2013). Nationally, half of all SNAP participants are children. One in four of all American children received SNAP benefits in 2012 (Isaacs and Healy 2012). Caseload growth after the Great Recession has been noted as being related to the weak macroeconomy and high unemployment, lower incomes and widening inequality (Ziliak 2013; Klerman and Danielson 2011; Ganong and Liebman 2013). More generally, participation has grown in the last ten years among full-time, year-round workers, those with a college education and those with household incomes between 100 and 200 percent of the federal poverty threshold (Ziliak 2013). The growing levels of SNAP participation as a work-support among higher educated but low-income workers should lead to high levels of joint participation with UI.

Research on SNAP during this period shows that the program blunted the effect of the recession substantially, reducing the number of households experiencing poverty by 14-16 
percent (Tiehan, Joliffe and Smeeding 2013; Tiehan, Joliffe and Gundersen 2012) and acting as a buffer against food insecurity (Nord and Prell 2011; Nord 2011; Pilkauskas, Currie and Garfinkel 2012). Research from the Fragile Families study estimates that without the availability of SNAP, the number of households experiencing food hardship would have doubled in 2008 (Pilkauskas, Currie and Garfinkel 2012).

Historically, research on UI has largely focused on the effects of the availability of UI benefits on unemployment duration and job search. Although data sources and methods vary, estimates generally suggest that the extension of UI benefits beginning in 2008 resulted in smallto-modest increases in national unemployment, perhaps by as much as 2 percentage points, and an increase in unemployment durations by two to five weeks. ${ }^{6}$ Among unemployed individuals, UI is more likely to be accessed by those with a college degree and by whites than by less educated workers and Black or Hispanic workers (Gould-Werth and Shaefer 2012). Additionally, other evidence suggests that low-educated single mothers are less likely to turn to UI during periods of unemployment than to SNAP (Shaefer and Wu 2011).

Given the recent growth in UI caseloads, the issue of joint participation between UI and other social safety net program is spawning a growing body of research. While Rothstein and Valletta (2013) examine participation in any social safety net program from a wide set of programs (SSI, food stamps, and cash welfare) for UI exhaustees, others have chosen to focus more narrowly on the possible substitution of UI for disability insurance (Linder 2011; Lindner and Nichols 2012; Rutledge 2012). Closer to the present study, the interaction of SNAP and UI is the focus of a very nice analysis for the state of Michigan (O’Leary and Kline 2013). O’Leary and Kline focus on the universe of all UI applicants in Michigan, obtaining results that support

\footnotetext{
${ }^{6}$ For consensus results, see Farber and Valletta (2013), Mazumder (2011), and Elsby, Hobijn and Sahin (2010). Rothstein (2011) argues effects are substantially smaller, whereas Barro (2010) argues for larger effects.
} 
the common assumption that overlap between the two programs is low: SNAP receipt is negatively associated with meeting the eligibility criteria for UI participation. Additionally, SNAP entry is higher among UI applicants deemed ineligible, suggesting that SNAP is operating as a safety net for the potential UI population. Michigan is quite different from Florida, the focus of the current study, in several regards. First, UI benefits in Michigan (\$117 minimum and \$362 maximum weekly) are much higher than those in Florida, which make it much more difficult to jointly participate in SNAP and UI in Michigan than in Florida. Second, the Michigan state economy has been struggling for some time, reflecting a long-term decline in manufacturing employment that, if not unique, is much greater than most states. Additionally, extended benefits of 13-weeks were triggered during the 2003 recession, generating different expectations about UI benefit length among potential participants. Michigan’s unusual UI program history may influence program usage in ways that limit the generalizability to most other states.

The current paper draws from data assembled in a project bringing together researchers to consider how the Great Recession has impacted the interaction of SNAP and UI. Some preliminary tabulations are provided in Anderson, Kirlin and Wiseman (2012). Results presented there for five states do suggest that in a substantial number of cases, perhaps one-third of the total in which there is some connection between SNAP and UI, recipients join the SNAP caseload after exhausting UI. More common, especially following the recession, are cases where there is concurrent take-up between UI and SNAP. Concurrent joint participation is highest in Florida among the five states examined (Michigan is among them). Thus, the present examination of Florida provides a unique opportunity to explore in more detail the changing 
characteristics of joint participants and their full pattern of benefit receipt in a state where the connection between UI and SNAP is relatively strong.

\section{Data}

Monthly data on participants in regular SNAP for January 2003-March 2010 come from administrative case records maintained by the Florida Department of Children and Families (DCF) in computer readable form. The information in these records includes monthly benefits paid and reported income, as well as demographic and geographic characteristics of all eligible individuals and their households. Normally, benefits are paid on a monthly basis, and any month in which a benefit check was provided to the household is counted as a month of SNAP receipt for each eligible individual in the household. ${ }^{7}$ However, we "smoothed” SNAP spells to remove interruptions of a single month to account for administrative churn. ${ }^{8}$

Data on employment and earnings come from quarterly earnings records from all covered employers in the state maintained by the Florida Unemployment Insurance system. We also utilize weekly data on UI benefit receipt obtained from the Florida Agency for Workforce Innovation. We code any month containing the Saturday of a week in which UI payments were made as a month of UI receipt for the individual identified as the payee. These data are available for the period October 2006-March 2010. Our analysis dataset is obtained by merging UI benefit data and UI wage record data to files containing the universe of SNAP recipients. The unit throughout our analyses is an individual, and UI benefit receipts and earnings are those accruing

\footnotetext{
${ }^{7}$ Payments are provided to the household as a unit, but there may be family members omitted from the count of eligible recipients. The largest category is adults in "child only" cases, but since our analysis focuses on those age 18 or older, these are minimal importance.

${ }^{8}$ Hence, any month coded on the original file as nonreceipt in which SNAP was received in both the immediately prior and succeeding months was coded as SNAP receipt. Our other work with these data suggests that in a substantial share of such cases, recipients received SNAP back payments in the subsequent month or two. Even when back payments do not occur, we believe the process by which recipients exit and return to SNAP is likely to differ for those with a single month of nonreceipt. Aggregate caseload information is available at Florida Department of Children and Families (2013).
} 
to the individual. Reported SNAP receipts apply to the household in which the individual is a SNAP-eligible member.

The analyses that follow are limited to SNAP recipients age at least 18 and less than 65 . Unemployment Insurance receipt outside that age range is very low, in large part because of the structure of program rules. This means that SNAP “child only” cases are omitted, since any adults in the household are not considered SNAP recipients. Those households that have more than one adult who is listed as a SNAP recipient in this age range can contribute more than one individual to the analysis.

A significant limitation to our work is that we do not have access to the universe of UI applicants or UI recipients: Our study is bound instead by the universe of SNAP participants. While this significantly shapes the research questions that we can address and the analytic strategies that are appropriate, our situation is hardly unique. To our knowledge, there is only one paper to date that examines joint participation between UI and SNAP with the UI universe from state administrative data (O’Leary and Kline 2013), and we have already noted the significant limitations of their work above. Other work on UI and SNAP relies upon nationally representative datasets such as the Current Population Survey or Survey of Income and Program Participation, in which longitudinal panels are quite short and significant issues with measurement error in the reported participation rates of social welfare programs have been noted (Meyer and Goerge 2011; Meyer, Mok and Sullivan 2009).

\section{Joint Receipt in UI and SNAP}

As a consequence of the conceptual and administrative division in program operations, joint participation in the UI program and SNAP was historically relatively rare in Florida, with only 12 percent of the SNAP population receiving UI until mid-2008. Figure 3 shows that in 2008, 
shortly after the onset of the recession, this proportion jumped dramatically, growing to over 10 percent by 2010. The proportion of new SNAP recipients receiving UI was appreciably higher, reflecting the fact that UI benefits were likely to be exhausted prior to departure from SNAP. Prior to the recession, this number was trending up from about 3 percent in 2006 to 6 percent by the end of 2007. In 2008, the proportion of new SNAP recipients receiving UI exhibited a dramatic jump, with the proportion growing to $12-14$ percent by the end of 2008. ${ }^{9}$

The growth in joint participation is related to both the high level of state unemployment and the change in federal UI benefit policies. Spikes are visible in the level of joint participation with implementation of the federal Emergency Unemployment Compensation (EUC) program in summer 2008 as well as each time that the EUC program was extended, in both November 2008 and November 2009. Thus, the population who are eligible to jointly participate in UI and SNAP has greatly expanded over the time period. However, as noted by Anderson et al. (2012), growth in concurrent SNAP-UI participation was particularly apparent in Florida.

Figure 4 shows that movements off of UI for SNAP recipient fell dramatically with the recession. Until mid-2008, when the maximum UI eligibility period was capped at 26 weeks for most recipients, 25 percent of UI participants discontinued receipt each month. However, by 2009, monthly discontinuations had declined to 5-10 percent. Declining exits are the result of

\footnotetext{
${ }^{9}$ Given the very large size of our population, measures of statistical significance imply that all measures are estimated with high levels of precision. In Figure 3, for example, the standard errors for the reported proportions are usually less than 0.05 percent, meaning that even substantively unimportant differences are statistically significant. Similarly, estimates of mean dollar values, presented in Tables 1-4, have standard errors that are generally less than 1 percent of means. For that reason, we suppress standard errors and other measures of statistical significance throughout the paper; the reader can assume that any difference commented on is statistically significant, usually at well beyond conventional levels. It may be noted that our analysis is undertaken on the full population of SNAP recipients in Florida who meet our inclusion criteria, so statistical tests are not justified by conventional sampling error.
} 
both more difficult economic conditions that make it harder to find employment, as well as the ability to remain on the UI program for longer periods than ever before. ${ }^{10}$

Given the large increase observed in joint participation, we examine trends for different demographic groups: the most notable observation was that patterns were very similar for all of them. Figure 5 shows UI-SNAP joint receipt by gender. For both men and women, UI participation increases dramatically after onset of the recession, with men's participation increasing to about 12 percent and women's to just under 10 percent, both from an initial base level just under 2 percent. The higher rate for men undoubtedly reflects the greater growth in unemployment among men occurring during the recession (Michaelides and Mueser 2013).

The tabulation of joint UI-SNAP receipt by race is presented in Figure $6 .{ }^{11}$ While nonwhites are observed to have slightly higher levels of joint receipt prior to the Great Recession than Hispanics or whites, with the onset of the recession, the difference between nonwhites and Hispanics diminishes to the point of being negligible. Whites have a lower level of joint receipt than either nonwhites or Hispanics after the Great Recession, consistent with expectations informed by racial differences in levels of unemployment. But again, it is the similarity in patterns across the racial groups that is most striking.

We looked at differences by settlement (comparing urban and rural SNAP recipients), household composition (households with children, with elderly, with neither children nor elderly), and in each case patterns were quite similar. Each group sharply increased their level of joint participation after the Great Recession and particularly after the EUC program was

\footnotetext{
${ }^{10}$ Figure 4 presents the proportion of recipients receiving UI benefits in a given month who are not receiving UI benefits in the following month, contingent on receiving SNAP in both months. The proportion is essentially unchanged if the proportion is calculated including those receiving SNAP only in the first month.

${ }^{11}$ These racial categories are mutually exclusive, reflecting the fact that the Florida administrative data coded Hispanic as a racial category. Racial categories used in our analysis are whites, nonwhites (African American and other racial groups), and Hispanics. Approximately 90 percent of nonwhites are African American.
} 
introduced in July 2008. In general, where group differences in participation rates had been present previously, these differences grew in absolute value after the Great Recession although ratios did not change much.

What factors are associated with UI receipt for those in SNAP? We fitted a linear probability model predicting SNAP receipt on the basis of individual characteristics, region, and length of time receiving SNAP, including as well dummy variables for each month. As expected, we found that demographic factors explained some of the variation in UI receipt across individuals. We found that men, blacks, older individuals, those in households with children, and those just beginning a SNAP spell or early in a spell were more likely to receive UI.

Despite their impact, since most of these characteristics changed very little over the period of our study, they had essentially no role in the increasing importance of UI. Average age declined by less than a year, the proportion Black declined by two percentage points, and the proportion of households in various categories changed by no more than one or two percentage points. The largest change was for proportion male, which increased by just under 7 percentage points, but the estimated impact of the change was trivial, increasing the UI receipt by less than 0.1 percentage point. In the period following the onset of the recession, the average length of time since entering SNAP increased slightly. This caused UI usage to be lower than it would otherwise have been by up to 0.5 percentage points, or about 5 percent. ${ }^{12}$

\footnotetext{
${ }^{12}$ These results are available from the authors and are based on a linear probability model predicting UI receipt for individuals using measures for gender, race (three categories), children in household (three categories), elderly in the household, single-person household, region (five areas) and a rural county indicator, time receiving SNAP (10 categories), and age (linear, square and cubic), as well as dummies for each month. Given the large sample size, all coefficients are quite precisely estimated.
} 


\section{Sources of Income for SNAP Recipients}

The growth in the importance of UI is associated with changes in the income sources for new SNAP recipients, which is in part a reflection of a new kind of recipient being drawn into the program. Although SNAP recipients have low income because of the program's eligibility requirements, with the recession, the eligible population has expanded to include those with previously substantial incomes who have faced serious employment setbacks.

Table 1 provides information on income sources for new SNAP recipients for periods prior to the recession, as well as the period after onset of the recession, including the extended period of labor market distress that followed. Since data on earnings are available on a quarterly basis, this analysis provides information on the quarter prior to SNAP entry and on the quarter following SNAP entry. ${ }^{13}$

A comparison between periods confirms that UI participation for new SNAP recipients has increased dramatically. During the earlier period, 2.7 percent of recipients received UI benefits in the quarter prior to entry, whereas, in the later period, the number had increased to 7.1 percent. Earnings and employment provide a slightly more complex pattern. During the earlier period, some 43 percent of recipients had income in the quarter prior to SNAP entry, whereas that number had declined to 40 percent in the second period. Yet, for those who had income, earnings were nearly 20 percent higher in the second period. This implies that, among the employed, there is a larger share with higher prior earnings in the second period, confirming the stories of middle class families turning to SNAP in the face of job loss. Of particular interest, we note that the proportion employed after beginning SNAP is much lower in the later period. In the quarter after entry, whereas 41 percent of recipients were employed in the period prior to the

\footnotetext{
${ }^{13}$ Columns 1 and 2 focus on those who begin receiving SNAP at least six months prior to the recession in order to assure that our measures of income following program entry occur before the recession.
} 
recession, the number was only 33 percent after the onset of the recession. As a consequence, the SNAP caseload, particularly those not receiving UI, is poorer in the second period.

In both periods, we see that, for those receiving UI, these benefits are substantially greater than the SNAP payments received by the UI recipients' households. During the earlier period, the average recipient is in a household receiving SNAP benefits of $\$ 700$ in the quarter following SNAP entry, whereas, for the subset of individuals who receive UI benefits, the average UI benefit is $\$ 1,722$. Both SNAP and UI payments are higher after the recession, but UI remains much more important (\$2,139 versus \$858).

What happens to those who leave the SNAP caseload? Those who leave SNAP because of employment will generally not be eligible for UI benefits, so one might assume UI receipt would be unusual. However, exit from SNAP may also be due to employment of other household members, or it may reflect difficulties with SNAP recertification. Given extensions in the availability of UI benefits following the recession, we might well expect more individuals leaving SNAP would continue to receive UI. Table 2 allows us to examine the importance of UI benefits as well as the role of earnings following departure from the SNAP caseload. Since outcomes differ by length of spell, the table presents separate statistics by whether a SNAP spell lasts 10 or more months.

In the first period, 40-50 percent of those leaving SNAP had earnings in the subsequent quarter, whereas the proportion fell by more than 10 percentage points after the recession. The proportion with earnings for those ending longer SNAP spells is smaller, and the gap between periods is somewhat greater: After the recession, only about a quarter of those with spells of ten months or more have employment in the quarter after SNAP ends. 
Perhaps surprisingly, however, for those with earnings, the average earnings are about 10 percent higher in the second period for both spell lengths. It is important to recognize that a smaller proportion of recipients leave the rolls in the second period, so the higher earnings may partly reflect selection. Nonetheless, these results support the view, suggested by the higher prior earnings after the recession for employed new recipients (Table 1), that the recession may have forced additional individuals who differ from prior recipients to seek SNAP assistance.

As expected, the impact of the recession on UI benefit receipt for the quarter following departure from SNAP is particularly dramatic. Only about 2 percent of those leaving SNAP in the earlier period have UI benefits, whereas the number exceeds 10 percent for short-term SNAP recipients and 5 percent for longer-term recipients. In addition, not only are more of those leaving SNAP receiving UI benefits, but the total UI benefit payment, contingent on receiving benefits, is about 50 percent greater in the later period.

We also looked at differences in income sources by gender, race, settlement density, and household structure. As might be expected, contingent on working, earnings of women are somewhat below those of men (Table 3). Perhaps surprisingly, women are more likely to be working than men at all points, that is, prior to beginning SNAP, in the first quarter of SNAP receipt, and following the end of a spell. Changes that occur with the onset of the recession, and in particular the increased reliance on UI benefits, are essentially the same for men and women.

Comparing across racial groups (Table 4), we see that prior to and during SNAP spells, nonwhites are appreciably more likely to be employed than whites, and they are slightly more likely to receive UI benefits, although, in both cases, the average amount received by nonwhites, contingent on receipt, is lower. For nonwhites, the pattern of growth in UI with the recession is similar to that for the population as a whole, although the increase is somewhat less dramatic. 
Hispanics have lower levels of employment prior to SNAP receipt than either whites or nonwhites, and their reliance on UI benefits is lower than either group. Reliance on benefits does increase with the recession, but, in contrast to the other groups, those entering SNAP after the recession are more likely than those in the earlier period to be working. This implies that, among Hispanics, the recession brought onto SNAP more of those who had prior employment, making the new Hispanic SNAP entrants more like the other racial groups.

Other analyses (not reported) showed that the impact of the recession was similar across various subgroups. Our analysis of urban and rural counties confirmed that differences were small and shifts in patterns of UI use essentially the same. As expected, reliance on employment and UI benefits was higher for those in households with children and lower for those in households with elderly. One of the only cases where patterns differed by household structure was among SNAP recipients in households with elderly members: In that case, a slightly larger proportion of individuals had prior earnings after the recession than before, the reverse of the shift observed for other groups.

\section{Patterns of SNAP and UI Receipt}

One of the most important changes in the UI program following the onset of the recession was the length of maximum receipt eligibility, which increased from six months to nearly two years. This shift is reflected in the experience of recipients. Figure 7 presents the distribution of UI spell duration for concurrent or subsequent SNAP recipients, comparing spells prior to and following onset of the recession. ${ }^{14}$ For the first period, almost all UI spells ended within seven months, reflecting the 26-week maximum receipt limit in place at that time. In contrast, in the

\footnotetext{
${ }^{14}$ This analysis considers UI spells beginning while the individual was receiving SNAP or in the 12 months prior to receipt of SNAP.
} 
second period, although half of all UI spells lasted seven months or less, about a third of all spells lasted for 12 months or more.

In order to examine the dynamics of SNAP and UI receipt, we have constructed spells for each individual that identify the period of time during which SNAP, or SNAP and UI benefits were paid. Although the focus is on continuous periods of receipt (i.e., successive months in which benefits were received), we have expanded our definition of spells to include intervening periods of up to six months in which no benefits were received. Hence, an individual who receives UI compensation for three months, receives no benefits in the next four months, and then begins receiving SNAP, contributes a single spell. The value of this approach is that we are able to identify the extent to which participants cycle on and off a particular program, and the way in which they sequence their use of the two programs. Of particular interest, we are able to identify those who move from one program to another even when there are intervening periods in which they are without benefits. In the latter category, for example, are individuals who exhaust unemployment benefits and then turn to SNAP after several months when savings are depleted.

Since our interest is in joint receipt of SNAP and UI, only UI spells involving some SNAP receipt are included. This means that UI benefits that are observed within seven months of SNAP receipt are included in a spell, whereas other UI spells (separated by more than six months from SNAP receipt) are omitted. ${ }^{15}$

Table 5 provides a count of the number of spells for the two periods we will be considering, the 26-month period up through December 2007, the official start of the recession,

\footnotetext{
${ }^{15}$ Since our data include information only on individuals who received SNAP during the period of our study, we are not able to consider the universe of those who received UI benefits.
} 
and the 26-month period starting in January 2008. ${ }^{16}$ In order to account for the experience of all SNAP recipients, we include spells that begin or end outside the period in question, but we limit our analysis to patterns observed within the period.

In the first period, we see there are approximately 1.4 million spells, increasing to over 2.2 million spells in the second period. This reflects the dramatic growth in the SNAP population. In both periods, we see that the average number of spells per person is 1.07 or 1.08. Over 92 percent of individuals contribute a single spell, almost all of the remainder contributing just two spells.

Spells in both periods average 11-12 months in duration. It is important to recognize that because some spells are censored, many individuals will experience much longer spells than those observed here. Although it would be possible to estimate expected spell length based on exit hazards in effect within each period, the resulting synthetic spells would not reflect individual experiences that span the dramatic economic and policy changes occurring over time. It is important to keep in mind that our comparisons between periods account for spell truncation, since the two periods are of equal length.

We have coded spells to reflect the type of benefits and the order in which they were received, with S identifying receipt of SNAP only in a month, U unemployment benefits, B receipt of both types of benefits in a month, and $\mathrm{N}$ indicating an intervening period of up to six months with no benefits. A spell that began prior to the period begins with the code $\mathrm{C}$, and a spell completed after the period ends with a code of C. ${ }^{17}$ Hence, UBC identifies a spell beginning with one or more months of UI benefits, followed by a period in which both UI and

\footnotetext{
${ }^{16}$ Although the two periods do not cover the same set of calendar months, this difference is unlikely to be of importance, since our graphs suggest that any seasonal effects in the SNAP caseload and UI receipt statistics are overwhelmed by variation associated with the recession.

${ }^{17}$ Spells with nonreceipt in the month immediately prior to the beginning of the period or immediately after the end of the period are not counted as censored spells but are coded as starting or ending within the period.
} 
SNAP are received, with the spell extending beyond the end of the period. Table 6 specifies the coding system, Table 7 gives the distribution of SNAP-only spells, and Table 8 gives the distribution of the most common spells with both UI and SNAP.

Table 7 shows, as expected, that the proportion of SNAP-only spells declines between the periods: 93 percent of spells involve only SNAP in the first period, but that declines to 85 percent in the second period. In both periods, about 30 percent of all spells are SNAP spells that begin and end within the period (coded S), 40 percent are SNAP spells that are either left or right censored, and slightly under 10 percent are spells that span the full 26 months.

The last four lines in Table 7 identify spells that include periods of nonreceipt of up to six months, that is, cases of exit and subsequent return to SNAP. ${ }^{18}$ These make up 11.8 percent of all spells, or about one out of every eight SNAP-only spells in the period prior to the recession. Following the recession, the figure is 10.7 percent, so that, given the decline in the proportion of SNAP-only spells, their prevalence remains essentially unchanged. This suggests that the factors inducing movements on and off SNAP have not been substantially influenced by the recession, despite dramatic increases in the caseload.

Table 8 shows that the frequency distribution of particular spell types containing UI changed dramatically with the onset of the recession. As an example, consider the spell UBC, which begins with one or more month of UI benefit receipt, followed by a period in which both SNAP and UI benefits are received, which is then censored at the end of the period. Whereas in the earlier period, only 0.3 percent of spells followed this pattern, the number had increased to 1.8 percent for the later period.

\footnotetext{
${ }^{18}$ As noted above, if a SNAP spell was interrupted by a single month of nonreceipt, it was treated as a continuous spell. Hence, spells referred to here as including periods of nonreceipt will have at least two months of nonreceipt.
} 
Also listed is the ranking of each spell type in terms of frequency (among spells with UI receipt) in each period. Focusing on the ranking adjusts for the fact that many more spells included UI in the second period than in the first. Shifts in ranking over time are particularly notable. As an example, consider those cases that begin with UI benefit receipt, followed by a period of combined receipt, and then followed by a period of UI benefits only (UBUC and UBU), both highly unlikely in the earlier period, but among the top ten patterns in the later period.

Several comparisons may be of interest. The codes UBS, UBSC, UNS, UNSC and US indicate those patterns where initial UI receipt is transformed into exclusive SNAP use. There is little change in the importance of such spell types between the two periods. In contrast are those spells that end with UI receipt (possibly joint with SNAP receipt). For example, the UBC pattern accounts for only 0.3 percent of all spells in the earlier period, but accounts for 1.8 percent in the later period.

The inferences one can obtain from Table 8 are limited since only about half of observed spells fit the detailed patterns that are listed. For that reason, we have classified spells into four broad categories (definitions are provided in the lower panel of Table 6). The first category, UI with Embedded SNAP, identifies spells in which UI plays a dominant role throughout. In the period prior to passage of legislation, most UI spells were limited to six months, and so we would expect this pattern to be unusual. But, with longer UI spells following the recession, we expect that some households with long-term UI recipients would experience changes making them temporarily eligible for SNAP.

The second category identifies those individuals who are observed initially receiving SNAP exclusively but then shift to UI participation. Like the previous pattern, we would expect 
such a pattern to be relatively unusual in the earlier period, in part because unemployment occurs with relatively low frequency and most of those initiating a UI spell would have substantial earnings prior to layoff. In contrast, following the recession, the increased likelihood of job loss would place more cases at risk, and legislated UI extensions would have increased the value of applying for UI benefits.

The category SNAP with Interior UI identifies individuals who receive UI for a limited period of time within a spell that is dominated by SNAP. One case would be that of a working individual eligible for SNAP due to relatively low earnings and a large family who loses a job. In this case, UI could provide support during a possibly brief unemployment spell, but with SNAP as a continuous backdrop.

Finally, the category UI to SNAP identifies those initially relying on UI benefits who then turn to SNAP. The most obvious case is that in which an individual exhausts household resources during an extended period of unemployment, ultimately running out the clock on UI eligibility. SNAP might be accessed while still receiving UI benefits, shortly after UI benefit exhaustion, or possibly several months after the last period of UI benefits following a gradual depletion of savings.

Table 9 reports the distribution of spells in these four broad categories. Generally, results confirm conclusions based on spells in Table 8. Focusing on the columns under the "Observed" heading, we see that the greatest change between periods occurs where UI is the dominant type of receipt, that is, in which SNAP occurs in a spell that begins and ends with UI or with joint receipt (line 2 of Table 9). Whereas only 1.1 percent of all spells were in this category in the earlier period, 6.3 percent of the second-period spells were in this category. As a proportion of spells with UI, these spells grew from one-sixth to over two-fifths (columns 2 and 4). 
In contrast, those spells indicating that individuals turn to SNAP after a period of UI receipt have become relatively less important after the recession. Perhaps the prototype for combining UI and SNAP is the case of an individual who receives UI for some period and then, around the time those benefits are exhausted, begins receiving SNAP (line 5). Fully two-fifths of the spells that combine UI and SNAP in the first period fit this description, in contrast to only about a quarter in the second period.

Those spells in which an individual is originally receiving SNAP, and at some point receives UI benefits, and then returns to sole reliance on SNAP accounted for about one in five SNAP-UI spells in the earlier period (line 4). By the later period, such cases accounted for only one in ten. Finally, those spells that begin with SNAP receipt and end in UI receipt increased substantially, from 1.2 percent to 3.2 percent of all spells (line 3), but their share of joint SNAPUI spells remained about the same.

The middle panel of Table 9 shows that the proportion of SNAP-UI spells that are censored increased dramatically between periods. This shift was due largely to the growth in the number of spells that began in the second period and extended beyond the end (see line 8). More generally, however, spells were more likely to be censored because of an increase in SNAP-UI spell length, which is reported in Table 10. The average spell classified as UI with embedded SNAP was about six months in length in the earlier period but increased to 13.4 months in the later period. We can see that this growth was primarily due to an increase in the number of months of UI receipt. In the average spell during the earlier period, individuals received UI benefits for approximately five months, whereas that figure was nearly 12 months in the second period. As noted above, this reflects changes in the UI rules allowing for extended periods of UI receipt. It is clear that whereas, prior to the recession, UI was seldom of dominant importance in 
a combined SNAP-UI spell, after the recession, not only did the number of cases with UI increase, but so did the relative reliance on UI.

Those spells where SNAP was the dominant form of receipt, and where UI receipt was interior to SNAP, were generally long spells, averaging about 20 months. It is notable that for this category, which did not increase in importance between the two periods, the spell length increased very little. However, the relative importance of UI increased, with the average number of months receiving UI increasing from about four in the earlier period to nearly six in the later period.

The lower panel of Table 9 indicates the number of joint SNAP-UI spells that include a period of up to six months in which the individual received no receipt. In the earlier period, 40 percent of all such spells included a period of nonreceipt. This is consistent with results reported in Table 8, where among the more important patterns in the earlier period are those in which individuals experienced several months of nonreceipt between the end of UI and the start of SNAP (e.g., UNSC and UNS). In the second period, the number of spells with months of nonreceipt grew, but they were slightly less important among those with UI, accounting for only about 33 percent of joint SNAP-UI spells. This was, in part, due to the decline of the relative importance of spells such UNS. In both periods, a somewhat higher proportion of the more complex spells included periods of nonreceipt.

In the earlier section, we discussed how the joint use of SNAP and UI shifted for different groups. We undertook similar analyses by group for spells. The basic shifts resulting from the recession were reflected in all the groups. Nonwhites were somewhat more likely to maintain "traditional” patterns of joint use than were whites or Hispanics, but differences were small. 
As noted above, the changes in spell structure between the two periods reflect both the dramatic deterioration of labor market opportunities and legislation extending the length of the period in which UI benefits could be received. In order to gauge the relative importance of these two factors, we simulated UI benefit receipt in the second period as it would have occurred under the earlier UI regime. Since, prior to 2008, UI benefits in Florida could be received for no more than 26 consecutive weeks in most cases, the procedure involved truncating spells of UI receipt at 26 weeks. In addition, any UI benefits received so soon after a prior spell of benefits that it would likely have been prohibited in the earlier period were also omitted. ${ }^{19}$ Of course, our simulation provides only an approximation of what spells would have been like in the absence of the legislated extensions. Most important, they omit any behavioral impact. Without policies extending benefits, workers would have had greater incentives to seek out and accept employment. As noted above, the consensus estimates are that spells of unemployment were extended by two to five weeks because of behavioral responses to emergency unemployment legislation (Farber and Valletta 2013; Mazumder 2011; Elsby, Hobijn and Sahin 2010).

Simulated spells are tabulated in the rightmost columns of Tables 9 and 10. Of all SNAP and SNAP-UI spells in the simulation, 14.4 percent combined UI and SNAP, as compared with 15.0 percent of spells based on observed data. As might be expected, longer spells are less common in the simulations. For example, the spell UBC, which identifies spells where SNAP and UI are received in each month to the end of the period, is two-thirds less likely. In contrast, those spells that begin with UI receipt and end in SNAP (e.g., UBSC, UBS, UNSC) are more common.

\footnotetext{
${ }^{19}$ Our simulated UI spells omit any week of UI benefits for an individual who had received benefits for 26 weeks or more over the prior year. This approach is an approximation of the rules in effect in the earlier period, which limited UI compensation to 26 weeks in the year following the filing of a claim, and only covered those with earnings above a minimum in the preceding five quarters.
} 
The importance of legislation is particularly clear when we compare spells using the classification system. Comparing the middle and rightmost columns in Table 9, it is clear that the proportion of spells classified as UI with Embedded SNAP declines by about half in the simulation (line 2), whereas the spells that identify initial UI leading into SNAP receipt double

(line 5). In fact, the distribution of spells, normalized by the number of spells that combine SNAP and UI, looks quite similar for the simulated spells and those spells prior to the recession (compare columns 2 and 6). The simulated spells are also more likely to have periods of nonreceipt (lines 10 and 11) than observed spells in the second period, corresponding more closely to the earlier period as well. As might be expected, the simulated spells in the categories where UI dominates have fewer months of UI receipt (see Table 10).

Our conclusion is that increases in the number of SNAP spells involving UI receipt was driven almost entirely by the recession. However, contingent on a spell involving both SNAP and UI, the growth in the importance of UI was primarily a result of legislation that extended UI benefits. In the absence of such legislation, two-thirds of those spells combining SNAP and UI would have involved UI benefits running out followed by SNAP receipt (Table 9, line 5) or cases where SNAP receipt was of primary importance (line 4). In our observed data, in contrast, these classes of spells make up slightly more than a third of SNAP-UI spells.

\section{Conclusion}

In the wake of the Great Recession, the conceptualization of how the American social safety net supports disadvantaged families will require revision. The current paper provides results from an analysis that examines the interaction of two of the largest programs aiding disadvantaged populations in the United States, with a focus on changes occurring with the onset of the most serious economic downturn in many decades. The results make clear that the recession induced 
important changes in patterns of receipt. The number of people receiving SNAP grew dramatically. For a growing share of SNAP recipients, UI and SNAP were combined, and reliance on SNAP became secondary for many of these. Among recipient spells that combined SNAP and UI, prior to the recession, UI was of primary importance in about a third, whereas, after the recession, that number had increased to two-thirds. Our simulations show that although the growth in extended periods of UI is primarily a function of federal legislation, the increased likelihood that a household receives both UI and SNAP is due primarily to labor market weakness.

It may be useful to consider the expansion of UI use in terms of the overall growth in the SNAP caseload associated with the Great Recession. Because UI eligibility rests on work history and employment separation status, many disadvantaged workers are not eligible for benefits. In addition, some disadvantaged workers who may be eligible fail to apply for UI (Shaefer and Wu 2011; Gould-Werth and Shaefer 2012). Our data on SNAP spells illustrate the extent of hardship faced by disadvantaged workers with the onset of recession: The number of SNAP and SNAP-UI spells we tabulated was 57 percent higher in the period following the recession than in the period before, and the number of individuals in our sample receiving SNAP increased by nearly three-quarters of a million (Table 5), corresponding to about one out of every 15 Florida residents aged at least 18 but less than 65 . The growth in spells involving UI amounts to about 30 percent of the increase in all SNAP spells. This increase suggests that UI was of substantial benefit to many of those who began to receive SNAP benefits with the onset of the recession. On the other hand, that the net growth in SNAP was over three times as great as the growth in the number of joint SNAP-UI recipients makes clear that there are important limits to the cushion provided by UI to disadvantaged individuals when the economy is in distress. 


\section{References}

Anderson, T.; Kirlin, J. A. and Wiseman, M. (2012). "Pulling Together: Linking Unemployment Insurance and Supplemental Nutrition Assistance Program Administrative Data to Study Effects of the Great Recession.” USDA Agricultural Research Service, Lincoln, Nebraska. Available at: http://digitalcommons.unl.edu/usdaarsfacpub/943/.

Barro, Robert J. (2010). “The Folly of Subsidizing Unemployment,” Wall Street Journal, August 30, 2010.

Cappellari, Lorenzo and Jenkins, Stephen. (2013). “The Dynamics of Social Assistance Benefit Receipt in Britain.” Paper presented at the IZA/OECD/World Bank Conference on Safety Nets and Benefit Dependence, May.

Cody, S., Nogales, R. and Martin, E. S. (2008). Modernization of the Food Stamp Program in Florida. Washington DC: Mathematica Policy Research, Inc.

Coleman-Jensen, Alisha; Nord, Mark; Andrews, Margaret and Carlson, Steven. (2012). "Household Food Security in the United States in 2011." USDA Economic Research Service Report \#141. Available at: http://www.ers.usda.gov/publications/err-economicresearch-report/err141.aspx.

DeNavas-Walt, Carmen; Proctor, Bernadette D. and Smith, Jessica C. (2012). “Income, Poverty, and Health Insurance Coverage in the United States: 2011,” Current Population Reports, P60-243 (September). Washington, D.C.: U.S. Government Printing Office.

Elsby, M. W.; Hobijn, B. and Sahin, A. (2010). “The Labor Market in the Great Recession.” NBER Working Paper 15979, National Bureau of Economic Research, Cambridge, MA.

Falk, G. and Aussenberg, R. (2013). “The supplemental nutrition assistance program: categorical eligibility.” Report No. R42054. Congressional Research Service.

Farber, Henry. S. and Valletta, Robert. G. (2013). "Do Extended Unemployment Benefits Lengthen Unemployment Spells? Evidence from Recent Cycles in the US Labor Market.” Working Paper \#573, Princeton University, Industrial Relations Section. Available at: http://arks.princeton.edu/ark:/88435/dsp01th83kz40p.

Federal Reserve Bank of St Louis. (2010). “Median Duration of Unemployment.” (http://research.stlouisfed.org/fred2/graph/?s[1][id]=UEMPMED) Accessed February 14, 2010.

Florida Department of Children and Families (DCF). (2013). “Access Florida Food, Medical Assistance and Cash.” (http://www.dcf.state.fl.us/ programs/access/StandardDataReports.asp) Accessed March 2013.

Ganong, Peter and Liebman, Jeffrey. (2013). “Explaining Trends in SNAP Enrollment.” Mimeo, 
Harvard University.

Gould-Werth, A. and Shaefer, H. L. (2012). "Participation in Unemployment Insurance: Unemployment Insurance Participation by Education and by Race and Ethnicity,” Monthly Labor Review, October: 28-41.

Hansen, Jorgen; Lofstrom, Magnus; Liu, Singfei and Zhang, Xuelin. (2013). "State Dependence in Canadian Welfare Participation.” Paper presented at the IZA/OECD/World Bank Conference on Safety Nets and Benefit Dependence, May.

Isaacs, J. and Healy, L. (2012). “The Recession's Ongoing Impact on Children, 2012: Indicators of Children's Economic Well-Being,” Urban Institute, Washington, D.C. Available at: http://www.urban.org/UploadedPDF/412713-The-Recessions-Ongoing-Impact-onChildren-2012.pdf

Klerman, Jacob and Danielson, Caroline. (2011). "The Transformation of the Supplemental Nutrition Assistance Program,” Journal of Policy Analysis and Management 30(4): 863888.

Körnigs, Sebastian. (2013). "The Dynamics of Social Assistance Benefit Receipt in Germany.” Paper presented at the IZA/OECD/World Bank Conference on Safety Nets and Benefit Dependence, May.

Lindner, Stephan. (2011). "How Does Unemployment Insurance Affect the Decision to Apply for Social Security Disability Insurance?” Working paper, Urban Institute.

Lindner, Stephan and Nichols, Austin. (2013). "The Impact of Temporary Assistance Programs on Disability Rolls and Re-Employment.” Paper presented at the IZA/OECD/World Bank Conference on Safety Nets and Benefit Dependence, May.

Mazumder, B. (2011). "How Did Unemployment Insurance Extensions Affect the Unemployment Rate in 2008-10?” Chicago Fed Letter: 285.

Meyer, Bruce, and Goerge, Robert. (2011). "Errors in Survey Reporting and Imputation and their Effects on Estimates of Food Stamp Program Participation.” Working Paper, University of Chicago.

Meyer, Bruce; Mok, Wallace and Sullivan, James. (2009). "The Under-Reporting of Transfers in Household Surveys: Its Nature and Consequences.” Harris School Working Paper \#09.03, University of Chicago.

Michaelides, Marios and Mueser, Peter R. (2013). "The Role of Industry and Occupation in Recent US Unemployment Differentials by Gender, Race, and Ethnicity,” Eastern Economic Journal 39(3) (Summer): 358-386. 
Moffitt, Robert. A. (2013). “The Great Recession and the Social Safety Net.” Russell Sage Foundation Working Paper. Available at: https://www.russellsage.org/research/reports/great-recession-social-safety-net.

Nord, Mark. (2011). "How Much Does the Supplemental Nutrition Assistance Program Alleviate Food Insecurity? Evidence from Recent Programme Leavers," Public Health Nutrition, 15(5): 811-817.

Nord, Mark, and Prell, Mark. (2011). "Food Security Improved Following the 2009 ARRA Increase in SNAP Benefits.” ERR-116, U.S. Department of Agriculture, Economic Research Service, April.

O’Leary, Christopher J. and Kline, Kenneth. (2013). “Use of Supplemental Nutritional Assistance Program Benefits by Unemployment Insurance Applicants in Michigan during the Great Recession.” Unpublished manuscript, Upjohn Institute, Kalamazo, MI.

Pilkauskas, N. V.; Currie, J. M. and Garfinkel, I. (2012). “The Great Recession, Public Transfers, and Material Hardship,” Social Service Review, 86(3): 401-427.

Rothstein, Jesse. (2011). "Unemployment Insurance and Job Search in the Great Recession.” NBER Working Paper 17534, National Bureau of Economic Research, Cambridge, MA.

Rothstein, Jesse and Valletta, Robert. (2013). "Scraping By: Responses to Unemployment Insurance Exhaustion in the Aftermath of the Great Recession.” Paper presented at the IZA/OECD/World Bank Conference on Safety Nets and Benefit Dependence, May.

Rutledge, Matthew S. (2012). “The Impact of Unemployment Insurance Extensions on Disability Insurance Application and Allowance Rates.” Working Paper 2011-17, revised April 2012. Center for Retirement Research at Boston College, Chestnut Hill, MA:.

Shaefer, H. L. and Wu, L. (2011). "Unemployment Insurance and Low-Educated Single Working Mothers before and after Welfare Reform,” Social Service Review, 85(2): 205228.

Tiehen, Laura; Jolliffe, Dean and Gundersen, Craig. (2012). “Alleviating Poverty in the United States: The Critical Role of SNAP Benefits.” Washington, DC: Economic Research Service, USDA.

Tiehen, Laura; Jolliffe, Dean and Smeeding, Timothy. (2013). "The Effect of SNAP on Poverty.” Paper presented at the UKCPR-IRP conference Five Decades of Food Stamps. September 20, 2013.

U.S. Bureau of Labor Statistics. (2010). "Non-Farm Wage and Salary Employment.” Available at: http://www.bls.gov/eag/eag.fl.htm. 
U.S. Department of Agriculture (USDA). (2012, 2013). "Supplemental Nutrition Assistance Program: Number of Persons Participation.” Updated March 8, 2013. Accessed December 2012 and March 2013: http://www.fns.usda.gov/pd/snapmain.htm.

U.S. Department of Labor (DOL). (2013a). “Unemployment Insurance Chartbook.” Accessed July 2013: http://workforcesecurity.doleta.gov/unemploy/chartbook.asp.

U.S. Department of Labor. (2013b). “Unemployment Insurance Database.” Available at: http://workforcesecurity.doleta.gov/unemploy/content/data_stats/datasum12/ DataSum_2012_4.pdf.

Ziliak, James. P. (2013). "Who Uses SNAP, and When? The Role of the Economy, Policy and Demographics.” Presented at the UKCPR-IRP conference Five Decades of Food Stamps. September 20, 2013. 
Figure 1. Unemployment: U.S. and Florida, by Month

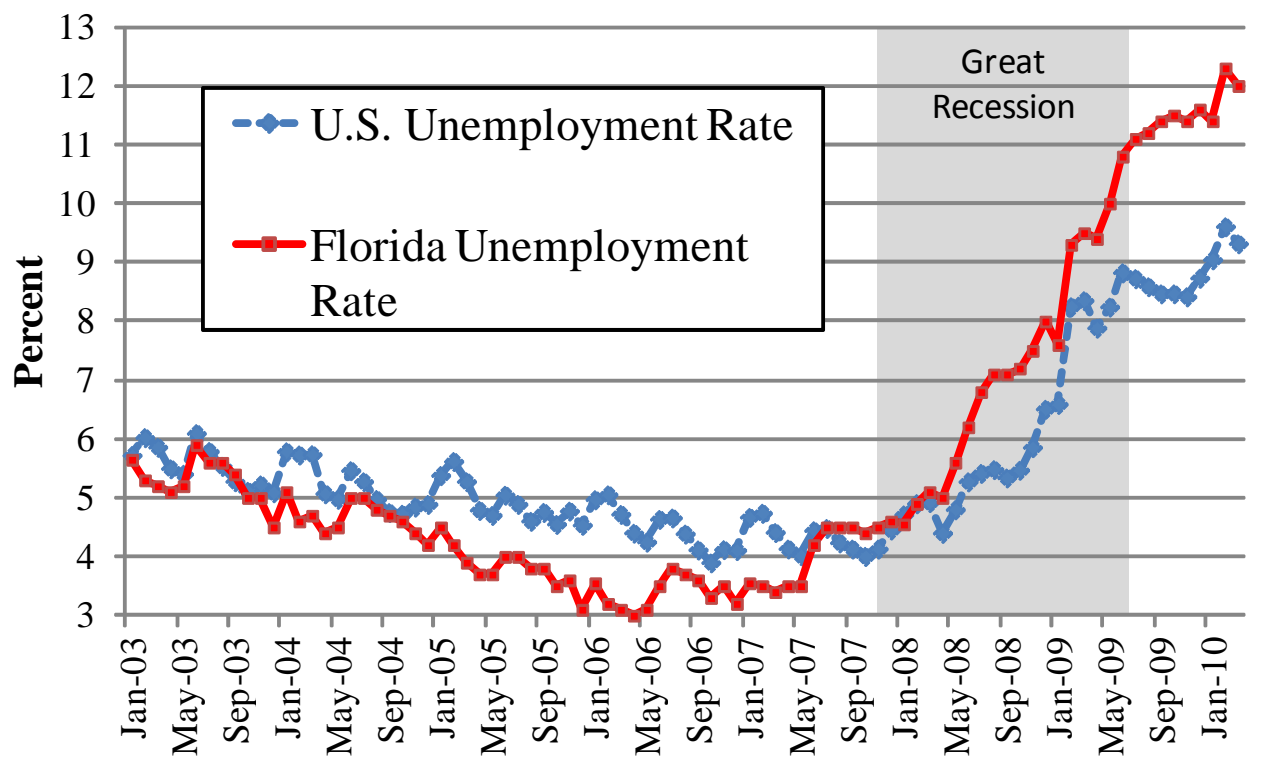

Figure 2. SNAP Caseloads: U.S. and Florida, by Month

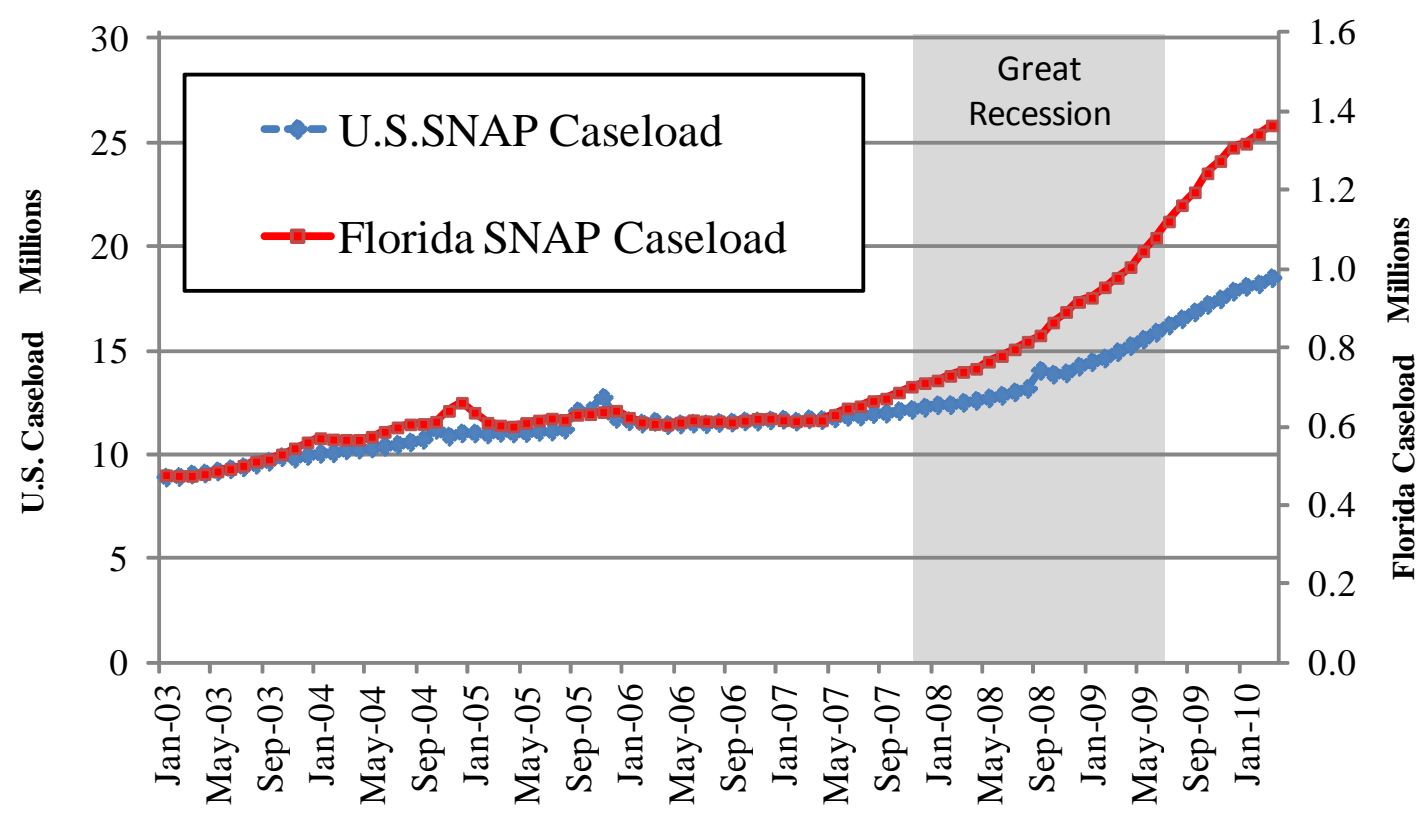


Figure 3. UI-SNAP Joint Receipt, by Month

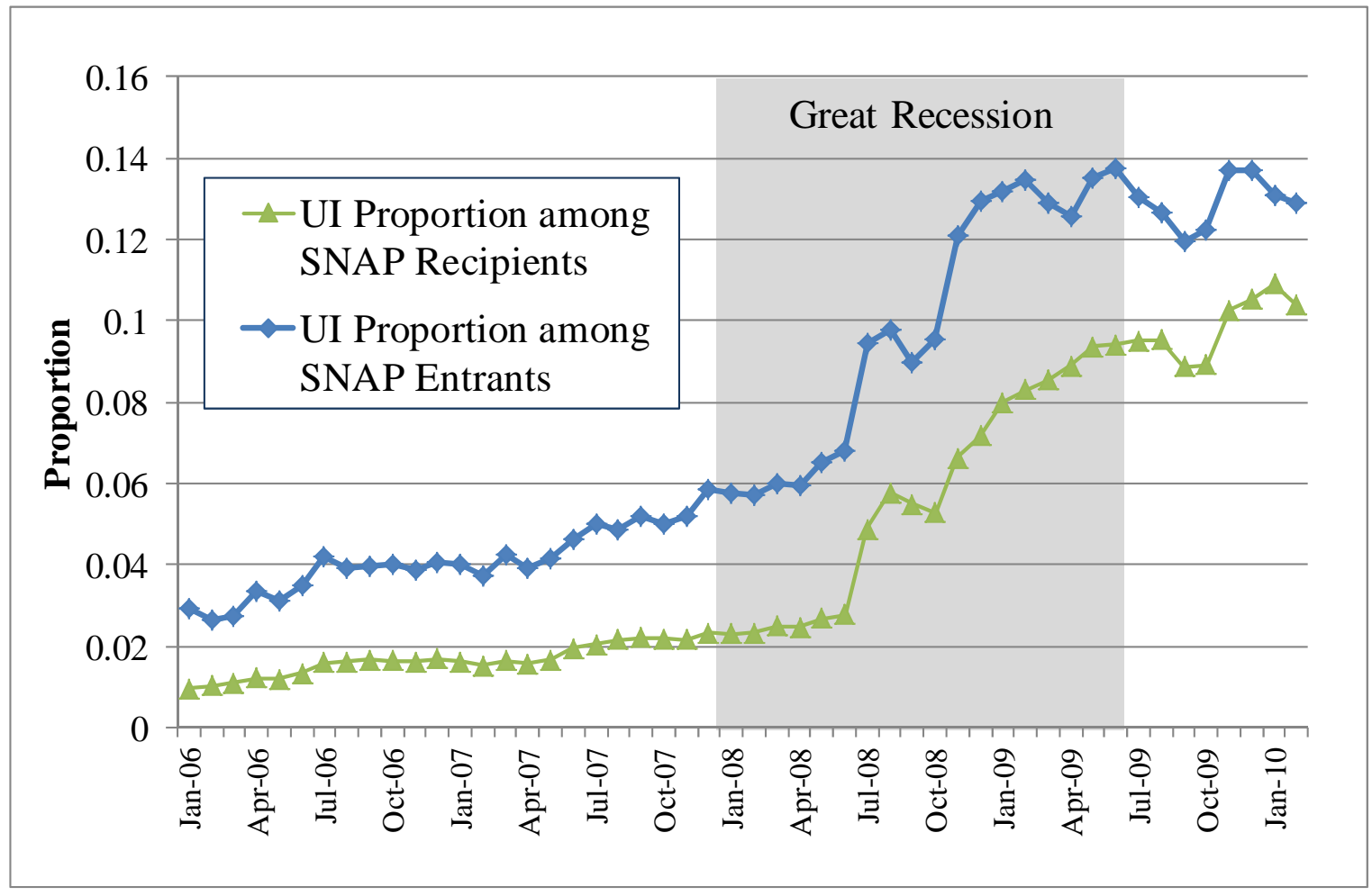

Figure 4. Probability that UI Recipient Exits UI: For SNAP Recipients, by Month

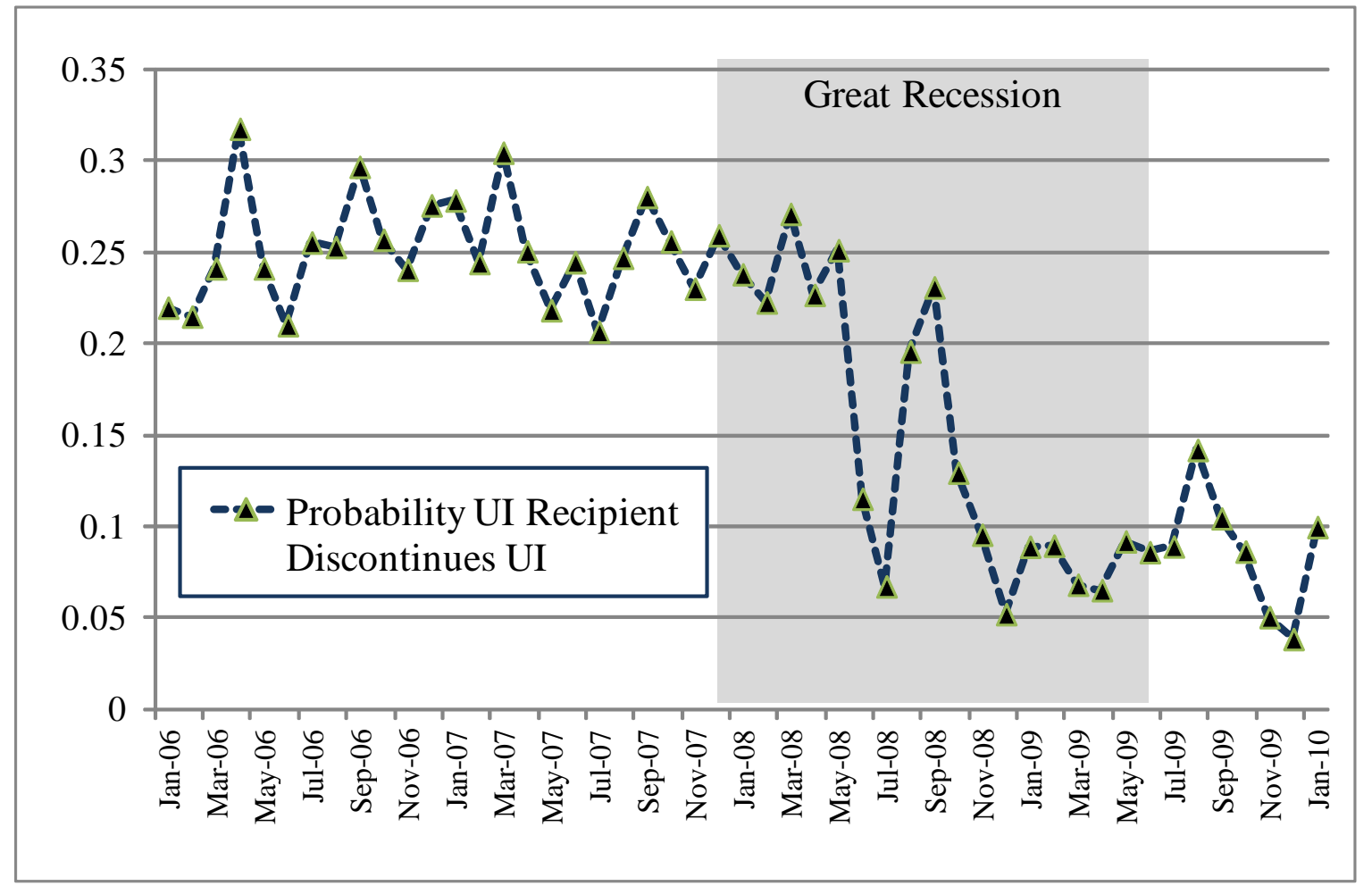


Figure 5. UI-SNAP Joint Receipt: UI Proportion among SNAP Recipients for Males and Females, by Month

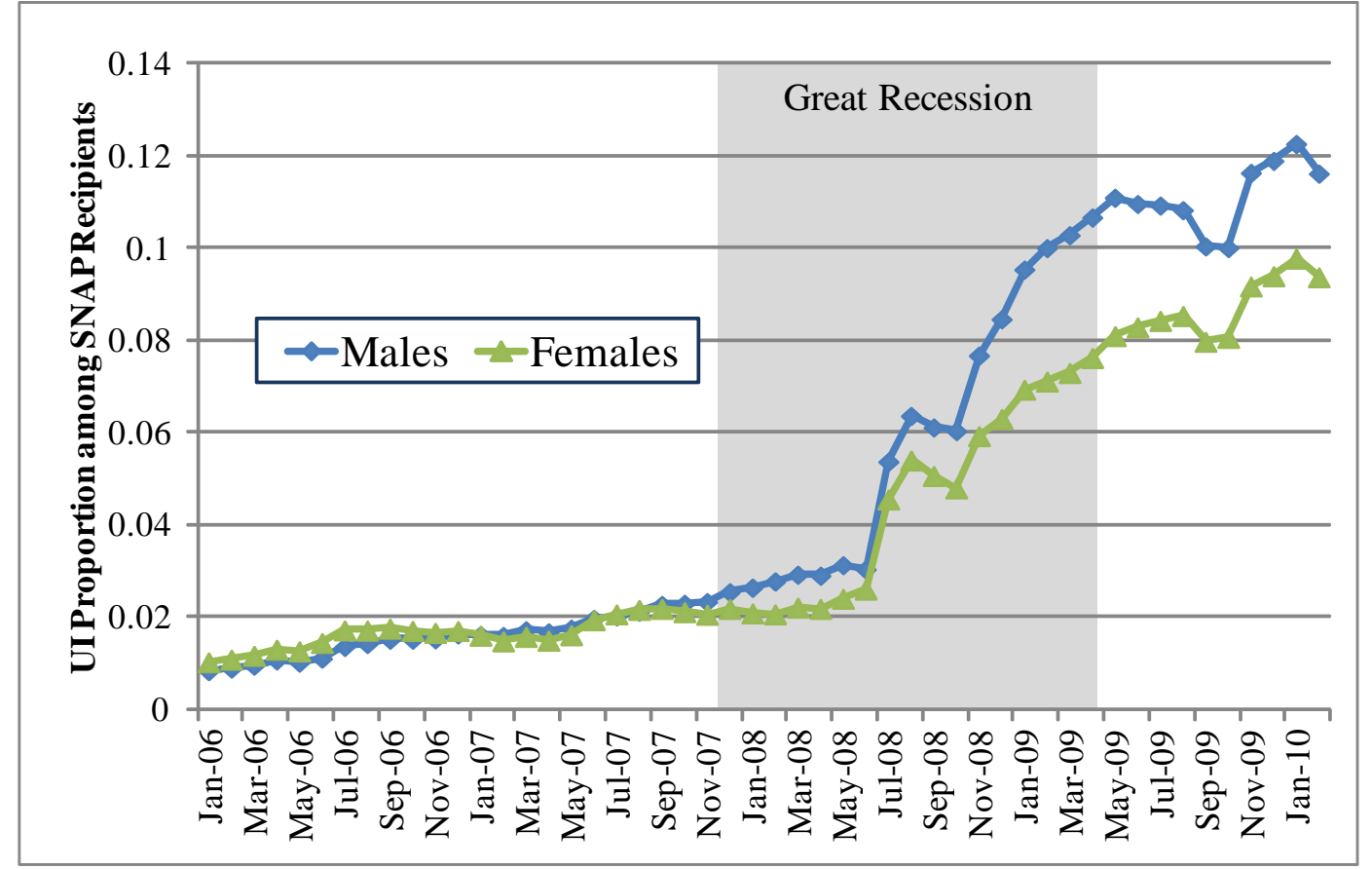

Figure 6. UI-SNAP Joint Receipt: UI Proportion among SNAP Recipients by Race, by Month

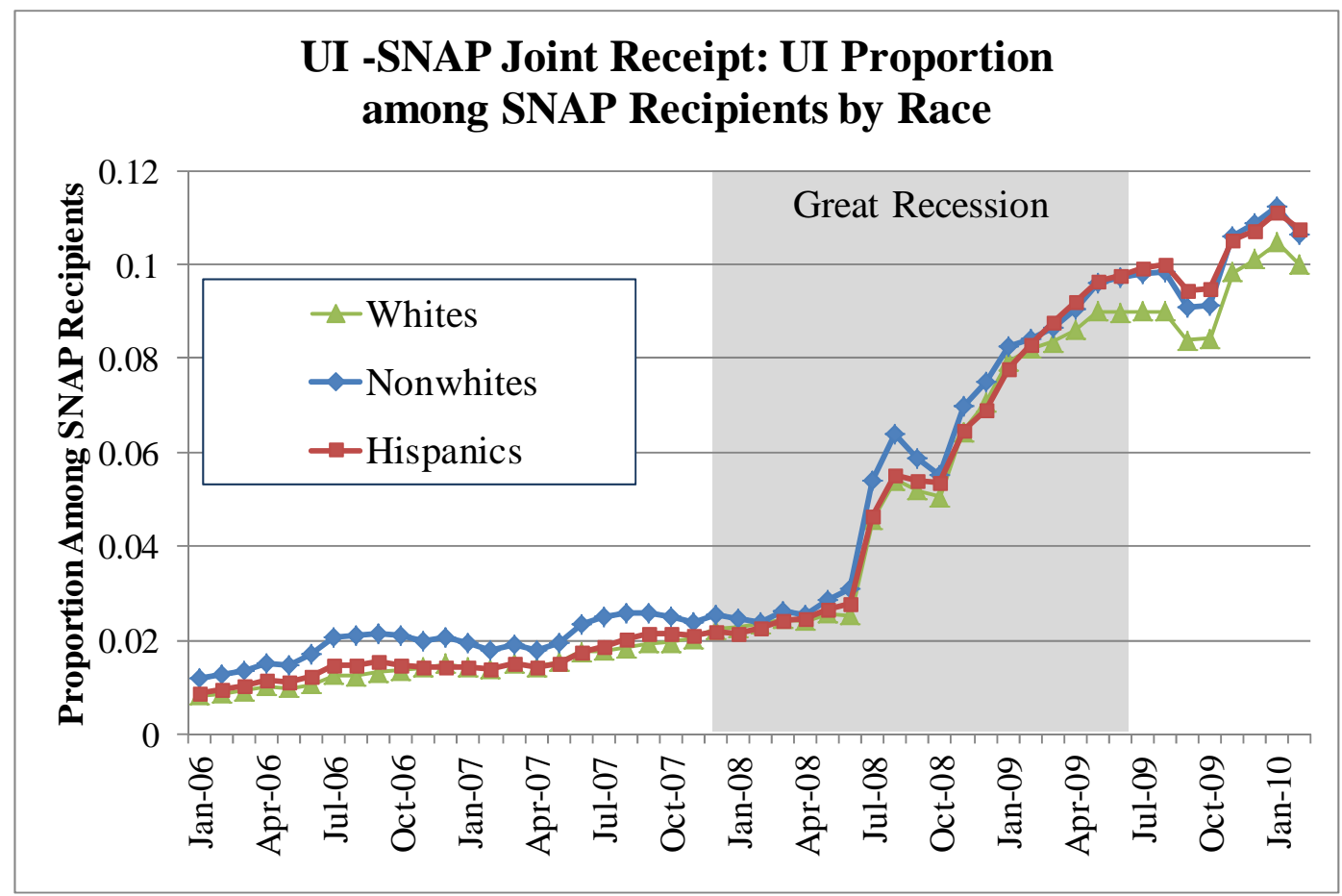


Figure 7. UI Spell Length Distribution: UI Spells with SNAP in 12 Months after Start

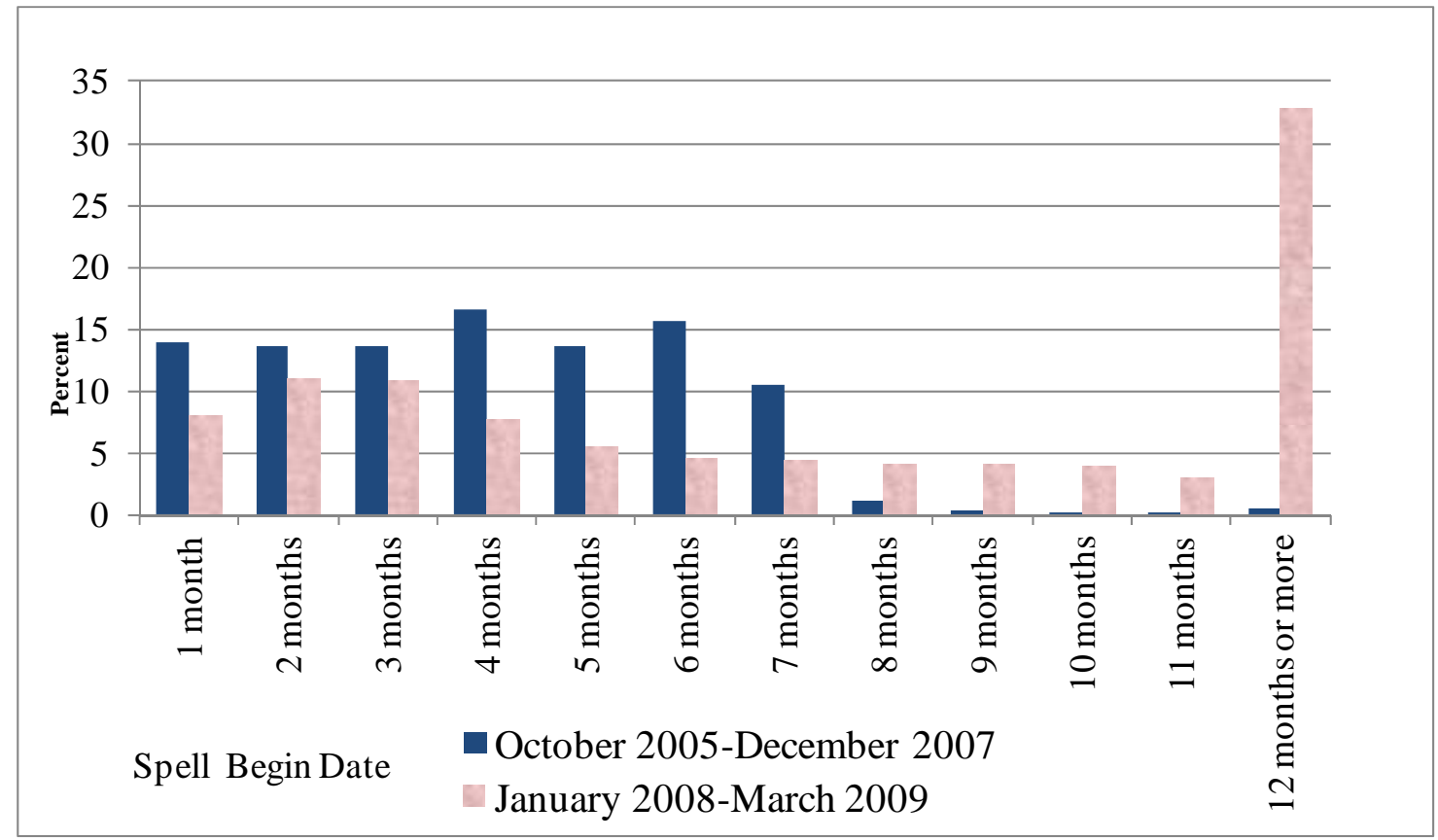


Table 1. Sources of Income for Spells

\begin{tabular}{|c|c|c|c|c|}
\hline & \multicolumn{2}{|c|}{ SNAP Spells beginning April 2006-June 2007} & \multicolumn{2}{|c|}{ SNAP Spells beginning April 2008-June 2009} \\
\hline & $\begin{array}{l}\text { Quarter Prior to } \\
\text { SNAP Entry }\end{array}$ & 1st Quarter After Entry & $\begin{array}{l}\text { Quarter Prior to } \\
\text { SNAP Entry }\end{array}$ & 1st Quarter After Entry \\
\hline 1. SNAP Entries & 616,565 & 455,525 & $1,103,865$ & 872,156 \\
\hline 2. \% with any Earnings & $43.2 \%$ & $41.1 \%$ & $40.1 \%$ & $32.5 \%$ \\
\hline 3. Average Earnings & $\$ 2,291$ & $\$ 1,967$ & $\$ 2,533$ & $\$ 1,645$ \\
\hline $\begin{array}{l}\text { 4. Average Earnings for } \\
\text { those with Earnings }\end{array}$ & $\$ 5,303$ & $\$ 4,785$ & $\$ 6,325$ & $\$ 5,066$ \\
\hline 5. \% with UI Benefits & $2.7 \%$ & $4.0 \%$ & $7.1 \%$ & $12.6 \%$ \\
\hline $\begin{array}{l}\text { 6. Average UI Benefit for } \\
\text { those with Benefits }\end{array}$ & $\$ 1,447$ & $\$ 1,722$ & $\$ 1,548$ & $\$ 2,139$ \\
\hline 7. Average SNAP Benefits & & $\$ 700$ & & $\$ 858$ \\
\hline
\end{tabular}

Table 2. Sources of Income After Completion of SNAP Spell: Quarter After SNAP Exit

\begin{tabular}{lcccccc}
\hline & \multicolumn{2}{c}{$\begin{array}{c}\text { SNAP Spells Ending } \\
\text { January 2006-September 2007 }\end{array}$} & & \multicolumn{2}{c}{$\begin{array}{c}\text { SNAP Spells Ending } \\
\text { April 2008-December 2009 }\end{array}$} \\
\cline { 2 - 3 } \cline { 5 - 6 } & $\begin{array}{c}\text { Spells Spanning 9 } \\
\text { or Fewer Months }\end{array}$ & $\begin{array}{c}\text { Spells Spanning 10 } \\
\text { or More Months }\end{array}$ & & $\begin{array}{c}\text { Spells Spanning 9 } \\
\text { or Fewer Months }\end{array}$ & $\begin{array}{c}\text { Spells Spanning 10 } \\
\text { or More Months }\end{array}$ \\
\hline 1. SNAP Exits & 530,166 & 314,263 & & 749,699 & 320,523 \\
2. \% of All Spells & $62.8 \%$ & $37.2 \%$ & & $70.1 \%$ & $29.9 \%$ \\
3. \% with Any Earnings & $49.8 \%$ & $40.8 \%$ & & $40.1 \%$ & $25.7 \%$ \\
4. Average for those with Earnings & $\$ 6,312$ & $\$ 6,367$ & & $\$ 6,946$ & $\$ 6,876$ \\
5. \% with UI Benefits & $2.1 \%$ & $1.7 \%$ & & $10.4 \%$ & $4.8 \%$ \\
6. Average UI Benefit for those with Benefits & $\$ 1,452$ & $\$ 1,246$ & & $\$ 2,244$ & $\$ 1,762$ \\
\hline
\end{tabular}


Table 3. Sources of Income During and Following SNAP Spells, by Gender

\begin{tabular}{|c|c|c|c|c|c|c|}
\hline \multirow[b]{3}{*}{ Males } & \multicolumn{3}{|c|}{ Prior to Recession } & \multicolumn{3}{|c|}{ After Onset of Recession } \\
\hline & \multicolumn{2}{|c|}{$\begin{array}{l}\text { SNAP Spells Beginning April } \\
\text { 2006-June } 2007\end{array}$} & \multirow{2}{*}{$\begin{array}{l}\text { SNAP Spells Ending } \\
\text { January 2006- } \\
\text { September 2007 } \\
\text { Quarter After Exit }\end{array}$} & \multicolumn{2}{|c|}{$\begin{array}{c}\text { SNAP Spells Beginning April } 2008 \text {. } \\
\text { June } 2009\end{array}$} & \multirow{2}{*}{$\begin{array}{c}\text { SNAP Spells Ending } \\
\text { April 2008- } \\
\text { December 2009 } \\
\\
\text { Quarter After Exit }\end{array}$} \\
\hline & $\begin{array}{l}\text { Quarter Prior to } \\
\text { SNAP Entry }\end{array}$ & $\begin{array}{l}\text { 1st Quarter } \\
\text { After Entry }\end{array}$ & & $\begin{array}{l}\text { Quarter Prior to } \\
\text { SNAP Entry }\end{array}$ & $\begin{array}{l}\text { st Quarter After } \\
\text { Entry } \\
\end{array}$ & \\
\hline$\%$ with Any Earnings & $39.0 \%$ & $38.1 \%$ & $43.3 \%$ & $36.9 \%$ & $29.4 \%$ & $34.0 \%$ \\
\hline Average for those with Earnings & $\$ 5,824$ & $\$ 5,314$ & $\$ 6,945$ & $\$ 6,850$ & $\$ 5,276$ & $\$ 7,286$ \\
\hline \% with UI Benefits & $2.6 \%$ & $3.8 \%$ & $1.8 \%$ & $8.2 \%$ & $14.3 \%$ & $10.3 \%$ \\
\hline Average UI Benefit for those with Benefits & $\$ 1,524$ & $\$ 1,878$ & $\$ 1,483$ & $\$ 1,634$ & $\$ 2,258$ & $\$ 2,280$ \\
\hline Average SNAP Benefits & & $\$ 652$ & & & $\$ 809$ & \\
\hline \multicolumn{7}{|l|}{ Females } \\
\hline \% with Any Earnings & $46.0 \%$ & $43.0 \%$ & $49.4 \%$ & $42.7 \%$ & $35.0 \%$ & $41.1 \%$ \\
\hline Average for those with Earnings & $\$ 5,007$ & $\$ 4,485$ & $\$ 5,922$ & $\$ 5,937$ & $\$ 4,919$ & $\$ 6,682$ \\
\hline \% with UI Benefits & $2.8 \%$ & $4.2 \%$ & $1.8 \%$ & $6.2 \%$ & $11.2 \%$ & $7.8 \%$ \\
\hline Average UI Benefit for those with Benefits & $\$ 1,400$ & $\$ 1,631$ & $\$ 1,279$ & $\$ 1,453$ & $\$ 2,013$ & $\$ 2,021$ \\
\hline Average SNAP Benefits & & $\$ 730$ & & & $\$ 900$ & \\
\hline
\end{tabular}

Table 4. Sources of Income During and Following SNAP Spells by Race

\begin{tabular}{|c|c|c|c|c|c|c|}
\hline \multirow[b]{3}{*}{ Whites } & \multicolumn{3}{|c|}{ Prior to Recession } & \multicolumn{3}{|c|}{ After Onset of Recession } \\
\hline & \multicolumn{2}{|c|}{$\begin{array}{l}\text { SNAP Spells Beginning } \\
\text { April 2006-June } 2007\end{array}$} & \multirow{2}{*}{$\begin{array}{c}\text { SNAP Spells Ending } \\
\text { January 2006- } \\
\text { September } 2007 \\
\\
\text { Quarter After Exit }\end{array}$} & \multicolumn{2}{|c|}{$\begin{array}{l}\text { SNAP Spells Beginning } \\
\text { April 2008-June } 2009\end{array}$} & \multirow{2}{*}{$\begin{array}{c}\text { SNAP Spells Ending } \\
\text { April 2008- } \\
\text { December 2009 } \\
\\
\text { Quarter After Exit }\end{array}$} \\
\hline & $\begin{array}{l}\text { Quarter Prior to } \\
\text { SNAP Entry }\end{array}$ & $\begin{array}{l}\text { 1st Quarter } \\
\text { After Entry }\end{array}$ & & $\begin{array}{l}\text { Quarter Prior to } \\
\text { SNAP Entry }\end{array}$ & $\begin{array}{l}\text { 1st Quarter } \\
\text { After Entry }\end{array}$ & \\
\hline \% with Any Earnings & $42.2 \%$ & $38.4 \%$ & $42.7 \%$ & $39.3 \%$ & $31.1 \%$ & $35.1 \%$ \\
\hline Average for those with Earnings & $\$ 5,203$ & $\$ 4,690$ & $\$ 6,086$ & $\$ 6,230$ & $\$ 4,929$ & $\$ 6,803$ \\
\hline$\%$ with UI Benefits & $2.6 \%$ & $3.6 \%$ & $1.6 \%$ & $7.1 \%$ & $12.3 \%$ & $8.7 \%$ \\
\hline Average UI Benefit for those with Benefits & $\$ 1,521$ & $\$ 1,805$ & $\$ 1,458$ & $\$ 1,610$ & $\$ 2,194$ & $\$ 2,226$ \\
\hline Average SNAP Benefits & & $\$ 678$ & & & $\$ 844$ & \\
\hline \multicolumn{7}{|l|}{ Nonwhites } \\
\hline$\%$ with Any Earnings & $50.6 \%$ & $47.6 \%$ & $52.8 \%$ & $42.8 \%$ & $34.3 \%$ & $40.3 \%$ \\
\hline Average for those with Earnings & $\$ 5,177$ & $\$ 4,628$ & $\$ 6,119$ & $\$ 6,150$ & $\$ 5,055$ & $\$ 7,015$ \\
\hline \% with UI Benefits & $3.1 \%$ & $5.0 \%$ & $2.2 \%$ & $7.1 \%$ & $13.0 \%$ & $9.2 \%$ \\
\hline Average SNAP Benefits & & $\$ 701$ & & & $\$ 820$ & \\
\hline \multicolumn{7}{|l|}{ Hispanics } \\
\hline$\%$ with Any Earnings & $35.6 \%$ & $37.7 \%$ & $46.7 \%$ & $38.3 \%$ & $32.8 \%$ & $40.3 \%$ \\
\hline Average for those with Earnings & $\$ 5,725$ & $\$ 5,146$ & $\$ 6,807$ & $\$ 6,689$ & $\$ 5,286$ & $\$ 6,962$ \\
\hline \% with UI Benefits & $2.4 \%$ & $3.5 \%$ & $1.7 \%$ & $7.3 \%$ & $12.9 \%$ & $9.0 \%$ \\
\hline Average UI Benefit for those with Benefits & $\$ 1,451$ & $\$ 1,774$ & $\$ 1,391$ & $\$ 1,549$ & $\$ 2,223$ & $\$ 2,190$ \\
\hline Average SNAP Benefits & & $\$ 733$ & & & $\$ 924$ & \\
\hline
\end{tabular}


Table 5. Spell Count: Two Periods

November 2005- J January 2008-

December 2007 February 2010

\begin{tabular}{lcc} 
Number of spells & $1,411,559$ & $2,219,786$ \\
Number of individuals & $1,302,349$ & $2,070,207$ \\
Average spells per person & 1.08 & 1.07 \\
Average spell length & 10.8 & 11.9 \\
\hline
\end{tabular}

Table 6. Coding Scheme for SNAP and SNAP-UI Spells

\section{Coding of Spell Runs}

\begin{tabular}{ll}
\hline S & One or more month of SNAP only receipt \\
U & One or more month of UI only receipt \\
B & One or more month of both SNAP and UI \\
N & One to six months of no receipt, internal to spell involving SNAP or UI receipt \\
C & Spell is censored \\
Example: SNB & $\begin{array}{l}\text { A spell beginning in a period with at least one month of SNAP receipt, followed by one } \\
\text { to six months with no benefit receipt, followed by one or more months of receipt of both }\end{array}$ \\
& UI and SNAP, ending within the period \\
Spell Categories & \\
\hline UI with Embedded & Spells starting with UI, or UI and SNAP; becoming SNAP, or UI and SNAP; ending in \\
SNAP & UI, or UI and SNAP (e.g., UB, UBC, UBU, UBUC, USU, UBU) \\
SNAP to UI & Spells starting in SNAP; ending in UI, or UI and SNAP (e.g., SBU, SBUC) \\
SNAP with Interior UI & Spells starting in SNAP; becoming UI, or UI and SNAP; ending in SNAP (e.g., SBS, \\
& SBSC) \\
UI to SNAP & Spells starting in UI, or UI and SNAP; ending in SNAP (e.g., UBS, BS, BSC) \\
\hline
\end{tabular}


Table 7. Frequency Distribution for SNAP Only Spells

\begin{tabular}{lcc}
\hline & $\begin{array}{c}\text { November 2005 - } \\
\text { December 2007 }\end{array}$ & $\begin{array}{c}\text { January 2008 - } \\
\text { February 2010 }\end{array}$ \\
\cline { 2 - 3 } & Proportion of Spells & Proportion of Spells \\
\cline { 2 - 3 } SNAP-Only Spells & $93.4 \%$ & $84.9 \%$ \\
\hline S & $30.9 \%$ & $27.9 \%$ \\
SC & $21.2 \%$ & $26.9 \%$ \\
CS & $19.7 \%$ & $10.3 \%$ \\
CSC & $9.7 \%$ & $9.2 \%$ \\
SNSC & $2.9 \%$ & $3.7 \%$ \\
SNS & $2.3 \%$ & $2.2 \%$ \\
CSNS & $2.5 \%$ & $1.3 \%$ \\
More Complex Cycles of SNAP & $4.1 \%$ & $3.5 \%$ \\
\hline
\end{tabular}

Table 8. Frequency Distribution for Spells with SNAP and UI

\begin{tabular}{lrrrr}
\hline & \multicolumn{2}{c}{$\begin{array}{c}\text { November 2005 - } \\
\text { December 2007 }\end{array}$} & \multicolumn{2}{c}{ January 2008 - } \\
& \multicolumn{2}{c}{ Froportion of Spells } & Proportion of Spells \\
\cline { 2 - 5 } Spells with UI and SNAP & $6.5 \%$ & Rank & $15.0 \%$ & Rank \\
\hline UBC & $0.3 \%$ & 6 & $1.8 \%$ & 1 \\
UBS & $0.5 \%$ & 1 & $0.6 \%$ & 4 \\
SBC & $0.2 \%$ & 11 & $0.8 \%$ & 2 \\
BC & $0.2 \%$ & 8 & $0.7 \%$ & 3 \\
UBSC & $0.3 \%$ & 4 & $0.4 \%$ & 6 \\
UBUC & $0.0 \%$ & 45 & $0.6 \%$ & 5 \\
UNSC & $0.3 \%$ & 2 & $0.3 \%$ & 7 \\
BS & $0.3 \%$ & 3 & $0.3 \%$ & 10 \\
UNS & $0.3 \%$ & 5 & $0.2 \%$ & 14 \\
SBSC & $0.2 \%$ & 9 & $0.3 \%$ & 11 \\
CSBSC & $0.2 \%$ & 7 & $0.2 \%$ & 13 \\
UBU & $0.1 \%$ & 20 & $0.3 \%$ & 9 \\
SBS & $0.2 \%$ & 10 & $0.2 \%$ & 16 \\
BSC & $0.2 \%$ & 12 & $0.2 \%$ & 15 \\
BUC & $0.0 \%$ & 36 & $0.3 \%$ & 8 \\
CSBC & $0.1 \%$ & 24 & $0.3 \%$ & 12 \\
BU & $0.1 \%$ & 18 & $0.2 \%$ & 18 \\
US & $0.1 \%$ & 14 & $0.1 \%$ & 23 \\
Other 1-, 2- or 3- Run Spells & $1.9 \%$ & & $1.8 \%$ & \\
Spells with 4 or more Runs & $1.9 \%$ & & $5.6 \%$ & \\
\hline Note: All spells with up to three runs were ranked by relative frequency. The listing in \\
the table includes the 18 spells with the highest average ranking over the two periods.
\end{tabular}


Table 9. Spell Type Shifts Between Periods: Summary for Spells with UI Receipt

\begin{tabular}{|c|c|c|c|c|c|c|}
\hline \multirow[b]{3}{*}{ Spell Description } & \multicolumn{4}{|c|}{ Observed } & \multirow{2}{*}{\multicolumn{2}{|c|}{$\begin{array}{c}\text { Simulated } \\
\text { January } 2008 \text { - } \\
\text { February } 2010 \\
\end{array}$}} \\
\hline & \multicolumn{2}{|c|}{$\begin{array}{c}\text { November } 2005 \text { - } \\
\text { December } 2007\end{array}$} & \multicolumn{2}{|c|}{$\begin{array}{l}\text { January } 2008 \text { - } \\
\text { February } 2010 \\
\end{array}$} & & \\
\hline & $\begin{array}{c}\text { Proportion of } \\
\text { Spells }\end{array}$ & $\begin{array}{l}\text { Proportion of } \\
\text { Spells with UI } \\
\end{array}$ & $\begin{array}{c}\text { Proportion of } \\
\text { Spells }\end{array}$ & $\begin{array}{l}\text { Proportion of } \\
\text { Spells with UI } \\
\end{array}$ & $\begin{array}{c}\text { Proportion of } \\
\text { Spells }\end{array}$ & $\begin{array}{l}\text { Proportion of } \\
\text { Spells with UI }\end{array}$ \\
\hline 1. All Spells with UI Receipt & $6.5 \%$ & $100.0 \%$ & $15.0 \%$ & $100.0 \%$ & $14.4 \%$ & $100.0 \%$ \\
\hline \multicolumn{7}{|l|}{ Spell Categories } \\
\hline 2. UI with Embedded SNAP & $1.1 \%$ & $16.7 \%$ & $6.3 \%$ & $42.1 \%$ & $3.1 \%$ & $21.2 \%$ \\
\hline 3. SNAP to UI & $1.2 \%$ & $17.7 \%$ & $3.2 \%$ & $21.3 \%$ & $2.1 \%$ & $14.5 \%$ \\
\hline 4. SNAP with Interior UI & $1.5 \%$ & $22.9 \%$ & $1.7 \%$ & $11.0 \%$ & $2.8 \%$ & $19.1 \%$ \\
\hline 5. UI to SNAP & $2.8 \%$ & $42.7 \%$ & $3.8 \%$ & $25.6 \%$ & $6.5 \%$ & $45.2 \%$ \\
\hline \multicolumn{7}{|l|}{ Censoring } \\
\hline 6. Begin and End in Period & $2.5 \%$ & $37.9 \%$ & $3.2 \%$ & $21.4 \%$ & $4.7 \%$ & $32.8 \%$ \\
\hline 7. Begin Prior to Period, End in Period & $0.8 \%$ & $12.8 \%$ & $1.0 \%$ & $6.5 \%$ & $1.2 \%$ & $8.3 \%$ \\
\hline 8. Begin in Period, End Following Period & $2.4 \%$ & $37.3 \%$ & $8.7 \%$ & $58.2 \%$ & $6.8 \%$ & $46.9 \%$ \\
\hline 9. Begin Prior to Period, End Following Period & $0.8 \%$ & $11.9 \%$ & $2.1 \%$ & $13.9 \%$ & $1.7 \%$ & $12.0 \%$ \\
\hline \multicolumn{7}{|l|}{ Disruption } \\
\hline 10. Contain no period of nonreceipt & $3.9 \%$ & $60.2 \%$ & $10.1 \%$ & $67.4 \%$ & $9.1 \%$ & $63.4 \%$ \\
\hline 11. Contain period of nonreceipt & $2.6 \%$ & $39.8 \%$ & $4.9 \%$ & $32.6 \%$ & $5.3 \%$ & $36.9 \%$ \\
\hline
\end{tabular}

Note: Spell category definitions are provide in Table 6. Simulated spells truncate UI receipt to correspond with regulations in effect prior to the recession.

Table 10. Spell Lengths and Months of UI Receipt for Spells with UI Receipt

\begin{tabular}{|c|c|c|c|c|c|c|}
\hline & \multicolumn{4}{|c|}{ Observed } & \multirow{2}{*}{\multicolumn{2}{|c|}{$\begin{array}{c}\text { Simulated } \\
\text { January } 2008 \text { - } \\
\text { February } 2010\end{array}$}} \\
\hline & $\begin{array}{r}\text { Novemb } \\
\text { Decemb }\end{array}$ & $\begin{array}{l}\text { er } 2005 \text { - } \\
\text { er } 2007\end{array}$ & $\begin{array}{l}\text { January } \\
\text { Februa }\end{array}$ & $\begin{array}{l}2008- \\
\text { y } 2010\end{array}$ & & \\
\hline & $\begin{array}{c}\text { Mean Spell } \\
\text { Length }\end{array}$ & $\begin{array}{c}\text { Mean Months } \\
\text { UI Receipt }\end{array}$ & $\begin{array}{c}\text { Mean Spell } \\
\text { Length }\end{array}$ & $\begin{array}{c}\text { Mean } \\
\text { Months UI } \\
\text { Receipt } \\
\end{array}$ & $\begin{array}{c}\text { Mean Spell } \\
\text { Length }\end{array}$ & $\begin{array}{c}\text { Mean Months } \\
\text { UI Receipt }\end{array}$ \\
\hline $\begin{array}{l}\text { 1. All SNAP spells with UI } \\
\text { Spell Categories }\end{array}$ & 13.2 & 4.2 & 15.4 & 9.2 & 14.3 & 5.8 \\
\hline 2. UI with Embedded SNAP & 5.9 & 4.8 & 13.4 & 11.8 & 8.1 & 6.3 \\
\hline 3. SNAP to UI & 14.3 & 3.7 & 17.9 & 8.4 & 14.7 & 4.8 \\
\hline 4. SNAP with Intierior UI & 20.1 & 3.9 & 20.4 & 5.8 & 20.6 & 5.4 \\
\hline 5. UI to SNAP & 11.8 & 4.4 & 14.6 & 6.8 & 14.5 & 5.9 \\
\hline
\end{tabular}

